Revista lus et Praxis, Año 23, № 2, 2017, pp. 147 - 212

ISSN 0717 - 2877

Universidad de Talca - Facultad de Ciencias Jurídicas y Sociales

El sistema de acciones reales, parte especial:

acción reivindicatoria, publiciana y del art. 915

Fernando Atria

Trabajo recibido el 11 de marzo de 2016 y aprobado el 18 de octubre de 2016

\title{
El sistema de acciones reales, parte especial: acción reivindicatoria, publiciana y del art. 915
}

\section{THE SYSTEM OF REAL ACTIONS, SPECIAL PART: ACTIO REIVINDICATORIA, PUBLICIANA, OF ARTICLE 915}

FERNANDO AtrIA*

\section{RESUMEN}

Este artículo explica y después desarrolla una parte del sistema de acciones reales del Código Civil, lo que denomina la protección de la dimensión estática del dominio. Esta es la dimensión en la que el que reclama protección afirma (y debe probar) tener un derecho sobre la cosa. Ese derecho puede afirmarse relativamente (mejor derecho que el del demandado) o absolutamente (el demandante prueba positivamente reunir las condiciones para tener el derecho). Las acciones discutidas en este artículo son, entonces, la acción reivindicatoria (estática/absoluta) y la acción publiciana y la del artículo 915 (estáticas/relativas).

ABSTRACT

This essay explains and then develops one aspect of the Civil Code's system of actiones in rem, the aspect that corresponds to the "static" dimension of property, characterized by the fact that those who seek protection must claim (and prove) a right over the thing. This right can be proven either in an absolute way (the claimant proves to satisfy the conditions to have acquired the right) or in a relative way (the claimant proves to have a claim to the thing that is better than the defendant's). The actions discussed in this article are the rei vindication (static/absolute) and the actio publiciana and the action of article 915 Code Civil (both of them static/relative).

\section{Palabras Clave}

Código Civil chileno, Acción reivindicatoria, Acción publiciana, Acción del art. 915, Acciones reales, propiedad, posesión

KEY WORDS

Chilean Civil Code, Reivindication, Action publiciana, Article 915 action, Actiones in rem, property, possession

\section{Introducción}

\footnotetext{
* Profesor asociado, Facultad de Derecho, Universidad de Chile. Pío Nono 1, Providencia; fatria@ derecho.uchile.cl. Este artículo es un producto del proyecto FONDECyT 1130178, del cual el autor fue investigador principal. Agradezco la ayuda invaluable que me prestaron María Ignacia Besomi y Gonzalo Falcón, ayudantes de la Universidad de Chile. También agradezco la colaboración de Rosita Díaz y Antonia Morales, ayudantes alumnas de la Universidad Adolfo Ibáñez.
} 
Presentación general. Este artículo comienza la discusión de la parte especial del sistema de acciones explicado en general en "El sistema de acciones reales, parte general" ${ }^{\prime 1}$. La parte especial describe en particular los elementos del sistema y sus conexiones. Esa descripción permitirá mostrar las severas incoherencias que resultan del hecho de ser un sistema de acciones reales fundado en una noción fáctica de posesión (es decir, una noción de posesión como la del art. $700 \mathrm{CC}$ ) al que se le adicionó un régimen que concibe normativamente a la posesión (la posesión inscrita).

La parte especial del sistema de acciones se divide en dos. Primero, lo que será objeto de este artículo: acciones que miran al aspecto estático del régimen de las cosas, y distingue dentro de ellas las que suponen prueba absoluta del dominio y prueba relativa de mejor derecho. Luego, en otro artículo, estudiaremos las acciones que miran al aspecto dinámico del régimen de las $\operatorname{cosas}^{2}$. A las acciones que forman propiamente parte del sistema de acciones reales será necesario agregar, en el cuarto artículo y final, una acción que tendremos que decir es parte honoraria de ese sistema: la acción de precario ${ }^{3}$.

Una observación preliminar sobre cuestiones metodológicas. La doctrina chilena sobre cuestiones de derechos reales en general y acciones reales en particular es extraordinariamente escasa ${ }^{4}$. La excepción más notable (y todavía en desarrollo) es el trabajo del profesor Jorge Larroucau, que será discutido cuando sea oportuno. Que la doctrina sea escasa quiere decir que hay un severo déficit de construcción jurídica en esta materia. En efecto, la función de la doctrina es reconstruir la racionalidad de los textos legales por la vía de elaborar, a partir de ellos, conceptos que conformen un sistema. Una y otra vez veremos las consecuencias de esto en lo que se refiere al sistema de acciones reales. Pero ahora lo que me interesa destacar es que este déficit de reconstrucción racional es habitualmente compensado recurriendo a construcciones o reconstrucciones que han sido elaboradas en otros contextos. Estos otros contextos pueden ser muy variados: en algunos casos, son otras disciplinas, la más relevante de las cuales hoy en día es la economía; otras

\footnotetext{
1 AtriA (En prensa): "El sistema de acciones reales, parte general".

2 ATRIA (En prensa): "El sistema de acciones reales, parte especial. La dimensión dinámica del dominio".

3 ATRIA (En prensa): "Un integrante honorario del sistema de acciones reales: la acción de precario".

${ }^{4}$ Contenido en textos como Pérez (2014), pp. 387-421: “La protección del dueño ante quien retiene indebidamente un bien: análisis jurisprudencial del artículo 915 del Código de Bello"; Larroucau (2014): "La prueba completa del dominio en la acción reivindicatoria" y SelmaN (2011), pp. 57-80: "Artículo 915 del Código Civil: una solución jurisprudencial a la limitación de las acciones tradicionales".
} 
veces, se trata de otros sistemas jurídicos, en la forma de derecho comparado o historia del derecho o derecho romano; todavía otras veces, se trata de otros contextos de construcción, especialmente la jurisprudencia.

El esfuerzo de reconstrucción que se intenta aquí ignora todos estos otros contextos de reconstrucción sistemática, y en ese sentido pretende ser un trabajo de dogmática jurídica en el sentido estricto. Me apresuro a enfatizar que esto, por cierto, no implica ni sugiere que estos otros contextos de racionalización son poco interesantes o irrelevantes. Es precisamente al contrario. Pero para aprovecharlos es necesario haber hecho el intento anterior de reconstrucción dogmático-jurídica. La manera en que el sistema así reconstruido se vincula a la tradición jurídica occidental o permite la maximización de la utilidad es algo importante e interesante, que debe constituir el paso siguiente.

Un párrafo aparte merece la falta de discusión de la jurisprudencia, algo que ha sido observado por los revisores de este artículo y de los demás de la serie ( $y$, de hecho, de los revisores del proyecto Fondecyt del cual estos artículos son parte). El estudio de la jurisprudencia es, por cierto, importante para los efectos de comentario y crítica ${ }^{5}$. Pero en nuestra tradición jurídica la reconstrucción racional del derecho le corresponde a la academia, no a los jueces. Esto tiene consecuencias observables: primero, explica por qué nuestra práctica jurisdiccional es tan poco capaz de producir interpretaciones dominantes que poco a poco vayan solucionando de modo más o menos definitivo problemas de interpretación. En consecuencia, quien quiera extraer de la práctica judicial criterios de reconstrucción sistemática siempre podrá elegir lo que desee, porque en las cuestiones importantes todas las opciones relevantes normalmente estarán y permanecerán abiertas; segundo, implica que no es posible tratar las decisiones judiciales como si fueran textos doctrinarios porque eso ignora el efecto que en la decisión tiene la necesidad de dar al caso una decisión adecuada.

Por las razones anteriores, el estudio de las decisiones jurisdiccionales en casos particulares será totalmente ignorado aquí. La reconstrucción procederá sin atender a lo que los tribunales han dicho, salvo en dos sentidos: primero, a veces casos particulares y sus decisiones serán utilizados como ejemplos, sin reclamar para ellos más que esa calidad. Segundo, y más importante, no tomar en cuenta las soluciones o argumentaciones doctrinarias contenidas en decisiones particulares no implica ignorar que hay ciertas cuestiones que han sido más problemáticas que otras desde el punto de vista de su aplicación,

\footnotetext{
${ }^{5}$ Véanse los hasta ahora cuatro volúmenes publicados de la Revista de Derecho de la Universidad Adolfo Ibáñez, que comenta exhaustivamente toda la jurisprudencia de la Corte Suprema de cada año (aunque lamentablemente afectada por irregularidad en la publicación).
} 
ni que para solucionar estos problemas algunos desarrollos han ocurrido. El más notable en la materia que nos interesa (aunque no será tratado en este artículo $\left.{ }^{6}\right)$, por cierto, es de la acción de precario, que ha devenido en los hechos la principal acción real aunque en el sistema del Código no era tal. Aquí lo que se impone no es un análisis detallado de la jurisprudencia de precario, sino entender la razón que lleva a este desarrollo y las características de las soluciones que se han intentado.

Como lo que nos interesa no son los intentos judiciales de reconstrucción, sino los problemas que han surgido y los modos en que ellos han sido enfrentados, no será necesario analizar la jurisprudencia directamente y será suficiente descansar en trabajos de recopilación y comentario ya realizados ${ }^{7}$.

\section{El aspecto estático del régimen de las cosas}

Categorías de las acciones reales. Las acciones reales se dividen en tres categorías, resultado de dos dicotomías sucesivas. La primera es la distinción entre el aspecto dinámico y el aspecto estático del régimen de las cosas. Las acciones que miran al aspecto dinámico se basan en la calificación del desplazamiento del control sobre la cosa sin atender al derecho del actor; las que miran a la dimensión estática se basan en el derecho del actor sobre la cosa.

Las acciones que miran al aspecto estático del régimen de las cosas descansan o en la prueba absoluta del derecho (como la acción reivindicatoria) o en la prueba relativa de mejor derecho (como la publiciana o la del art. 915). La prueba es absoluta cuando lo probado es el derecho del actor con prescindencia de las pretensiones del demandado, mientras es relativa cuando todo lo que el actor necesita es probar que su derecho a la cosa es mejor que el del demandado. Esta es la parte especial que es objeto de este artículo.

\section{Prueba absoluta del dominio: la acción reivindicatoria}

La acción reivindicatoria es el paradigma de acción real, así como el dominio es el paradigma de derecho real. Pero esto no quiere decir que sea la acción más apropiada para defender el dominio; es precisamente al contrario. La acción reivindicatoria es la que en cuanto a sus requisitos de procedencia es la más exigente, y por eso si todo lo que tuviera el dueño

\footnotetext{
${ }^{6}$ Sino en otro referido monográficamente a la acción de precario: véase supra, № 2.

7 Como los de Rostión (2013): El precario en la jurisprudencia chilena (Santiago, LegalPublishing), Larroucau (2014): "La prueba completa del dominio" y antes, RifFo y SuÁrez (1996): La acción de precario ante la doctrina y la jurisprudencia (Santiago, ConoSur).
} 
para defender su dominio fuera la acción reivindicatoria su protección sería extraordinariamente escasa.

El profesor Daniel Peñailillo sostiene que aunque la reivindicatoria es "la gran acción protectora", "al menos entre nosotros, su eficacia suele presentarse debilitada, al punto que efectivos dueños intentan evitarla y llegan a emplearla con aprehensión". Según Peñailillo, esto se debe "a la regulación de la posesión, a las características del registro, a la prueba del dominio y la restricción del sujeto pasivo" ${ }^{\prime}$. Aunque algo de razón tiene, su explicación mezcla razones de distinta naturaleza, algunas de las cuales son un déficit de la regulación "entre nosotros" y otras que pertenecen a la idea misma de acción reivindicatoria.

En efecto, es verdad que la efectividad de la acción reivindicatoria es disminuida por "la regulación de la posesión" y "las características del registro", en lo que a mi juicio constituye una razón: la posesión inscrita. Esta es una de las principales conclusiones a las que al final arribaremos, pero no solo por referencia a la acción reivindicatoria: veremos que el sistema de acciones reales está construido sin considerar el régimen de posesión inscrita y que eso introduce problemas graves, tanto al régimen de la posesión como al de las acciones. Pero por lo mismo, la consideración de esto deberá quedar para más adelante.

No pueden enumerarse junto con lo anterior las otras dos razones que ofrece Peñailillo para explicar la inefectividad de la acción reivindicatoria: "la prueba del dominio y a la restricción del sujeto pasivo". Estas dos características de la acción reivindicatoria son la misma: esa acción no solo se funda en el dominio del actor, sino que se dirige en contra de quien precisamente, teniendo la cosa, impugna ese dominio por la vía de arrogárselo él mismo. De esto se sigue que es parte de la definición de la acción reivindicatoria (a) que se dirige contra el que tiene la cosa, pero adicionalmente reclama ser dueño de ella, porque en caso contrario la controversia no se trabaría entre dos sujetos cada uno de los cuales afirma ser dueño; y (b) que para intentarla exitosamente es necesario probar el dominio sin que para eso el demandante se pueda beneficiar de la presunción del inciso $2^{\circ}$ del artículo 700 , que beneficiará siempre al demandado. Nótese: (a) y (b) se implican recíprocamente. El artículo 2195, por ejemplo, dispone que la acción de precario la tiene "el dueño". Por consiguiente, el fundamento de la acción es el dominio; pero la acción se dirige en contra de quien tiene la cosa sin reclamar dominio (si reclama ser dueño es poseedor, y la que corresponderá, entonces, será la

8 Peñallillo (2006), p. 515. 
acción reivindicatoria), por lo que aunque el fundamento de la acción es el dominio para el actor será siempre suficiente probar su posesión.

\section{Definición y condiciones de procedencia de la acción reivindicatoria}

Definición y condiciones de procedencia de la acción reivindicatoria. Conforme al artículo 889.

La reivindicación o acción de dominio es la que tiene el dueño de una cosa singular, de que no está en posesión, para que el poseedor de ella sea condenado a restituírsela.

Con la definición a la vista, es posible identificar las condiciones bajo las cuales la acción reivindicatoria ha de ser ejercida.

(a) En primer lugar, debe tratarse de una cosa reivindicable. La definición usa la expresión "singular", a lo que se puede agregar, porque está implícito en la definición (se trata de una cosa de la que alguien es dueño), apropiable.

(b) En segundo lugar, la acción la tiene el dueño.

(c) Por último, la acción ha de dirigirse en contra del poseedor, con la pretensión de que sea condenado a restituírsela. Por eso, "la acción de dominio se dirige en contra del actual poseedor" (art. 895).

Es importante notar que lo riguroso de las condiciones de procedencia de la acción reivindicatoria no es arbitrario, no es solo consecuencia de una manifestación de voluntad del legislador que en todo momento podría haber sido de otro modo: ellos cumplen la función de identificar la controversia como una controversia genuina sobre el dominio. Esta cuestión será importante cuando identifiquemos los problemas que el régimen de posesión inscrita crea en el sistema de acciones, porque entonces observaremos que la reflexión jurídica, dada su orientación fundamentalmente forense, razona apremiada por la necesidad de solucionar esos problemas mediante interpretaciones más bien laxas de estos requisitos. Pero lo hace sin tener mayor conciencia de qué es lo que justifica las exigencias que son ignoradas (o creativamente interpretadas). El resultado es que esas soluciones arriesgan crear más problemas de los que solucionan, al contribuir a la disolución de las categorías formales que organizan la protección del dominio.

Estas cuestiones deben ser discutidas por separado en relación con cada una de las condiciones de la acción reivindicatoria, lo que haremos a continuación.

a. Cosas reivindicables. Debe tratarse de una cosa (i) corporal, (ii) singular, (iii) apropiable y (iv) no afecta a una prohibición de reivindicación.

(i) Cosas corporales. La exigencia contenida en el artículo 890: que se trate de una cosa corporal, es una exigencia cuya justificación es relativamente obvia. Después de todo, el derecho de dominio es un derecho sobre "cosa corporal" (art. 582). Es cierto que el artículo 891 permite la reivindicación de 
"los otros derechos reales" (con la excepción del derecho de herencia, porque ahí no se trata de una cosa singular), pero en este caso la cosa reivindicada no es el derecho real en tanto cosa incorporal, sino la cosa corporal sobre la cual el derecho real recae.

¿Hay contradicción en la consideración conjunta de los artículos 583, 889 y 890 ? El primero dispone que sobre las cosas incorporales hay una especie de dominio; el segundo, que la acción reivindicatoria es la del dominio; el tercero, que solo las cosas corporales pueden ser reivindicadas. ¿Cómo es que las cosas incorporales no pueden ser reivindicadas, si sobre ellas hay una especie de dominio? La respuesta es que lo que hay sobre las cosas incorporales no es dominio simpliciter, sino una especie de dominio, y por eso hay que decir que la regla del artículo 583 contiene una metáfora, no una especificación. El que recae sobre cosas incorporales es una "especie" de dominio en el sentido en el que la guerra fría es una "especie" de guerra (=algo que, aunque en rigor no es una guerra, puede ser tratada como tal desde uno o varios puntos de vista), no en el sentido en el que una vaca es una "especie" de mamífero".

Ahora bien, ¿por qué la restricción de la acción reivindicatoria a las cosas corporales? La razón es clara: una acción reivindicatoria de una cosa incorporal sería una acción personal. O quizás la mejor formulación es ligeramente distinta: la acción reivindicatoria no procede cuando se trata de cosas incorporales en la medida en que en esos casos se trataría de una acción personal. En los casos (inusuales) en que se puede reivindicar una cosa incorporal sin que eso implique el ejercicio de una acción personal, las cosas incorporales son reivindicables. Esos casos inusuales son casos en los que se reivindica un derecho real distinto del dominio, y por eso la regla del artículo $891^{10}$.

\footnotetext{
${ }^{9}$ La diferencia entre la metáfora y la especificación es fácilmente apreciable añadiendo a la afirmación original su negación. Cuando se trata de una metáfora, no hay contradicción; cuando es una especificación, sí: "En 1945 comienza la guerra fría que no fue, en rigor, una guerra" no contiene contradicción alguna. Pero "una vaca es un mamífero que no es, en rigor, un mamífero" es una contradicción. Si la regla del art. 583 es una metáfora, no hay contradicción en afirmar que sobre las cosas incorporales hay una especie de dominio que no es, en rigor, dominio. La explicación sería que cuando los derechos se comodifican, cuando la funcionalidad económica de los derechos se realiza tratándolos como objetos del intercambio y no, como es normal, como la forma jurídica del intercambio, tiene sentido aplicarles el régimen de las cosas. Véase la nota siguiente.

10 Esta manera de enfrentar la cuestión de cuán estrictamente las cosas incorporales son realmente cosas puede generalizarse. Aunque este es un problema al que es imposible hacerle justicia al pasar, la clave para entender la noción de cosa incorporal no está en la elaboración cuidadosa de los conceptos, sino en la funcionalidad económica. La situación normal es que los derechos no son objeto de intercambio, sino la forma jurídica del intercambio. Por eso, normalmente tratar a los
} 
(ii) Cosas singulares. Que se trate de cosas singulares implica que no puede reivindicarse nada más que una cosa singular ni nada menos que una cosa singular. Lo primero excluye las universalidades, lo segundo excluye las cuotas.

Cuotas. La exclusión de las cuotas implicada por lo dispuesto en el artículo 889 es seguida por su inclusión, conforme al artículo 892. Este permite la reivindicación de "una cuota determinada proindiviso, de una cosa singular".

Es importante notar que la regla del artículo 892 permite reivindicar cosas que conforme a la sola regla del artículo 889 no serían reivindicables. Como sostuvo Claro Solar.

Si para entablar la acción reivindicatoria de una cuota proindiviso de una cosa singular fuera necesario que esta hubiera salido de la universalidad jurídica por la adjudicación a favor de uno de los comuneros, no existiría tal reivindicación de cuota proindiviso, sino reivindicación del dominio de una cosa divisa, de la cosa singular en toda su integridad ${ }^{11}$.

El punto aquí es en realidad obvio: el artículo 892 permite la reivindicación de una cuota, y es insensato entender que las condiciones para las que proceda una reivindicación de cuota es que ya no se trate de una cuota, sino una de una cosa singular. Eso sería entender precisamente lo contrario de lo que el artículo 892 dispone. Por consiguiente, en los casos de esta disposición se tratará de un comunero en una comunidad actualmente existente que se dirige en contra de otro comunero o de un tercero (quien tenga la posesión) para que se declare que el dueño de la cuota respectiva es el demandante.

derechos como cosas produce un retorno al infinito que crea todo tipo de problemas conceptuales, para evitar los cuales se han desplegado muchos esfuerzos (probablemente el más logrado es el de GuZMán Brito (1995)). En ciertos casos, sin embargo, los derechos se comodifican, son tratados en el tráfico como objetos del intercambio. Entonces tiene sentido aplicarles el régimen de las cosas (que incluye la propiedad, la posesión, la tradición, etc.). Sobre la aplicación del régimen de las cosas a cosas incorporales, véase Caballero (2016), pp. 147-181. Lo dicho en esta nota no pretende ser novedoso, sino al contrario: los problemas suscitados por la noción de "cosa incorporal" comienzan cuando se asume que la verdadera naturaleza de todo crédito es ser una cosa a la que puede ser aplicado el régimen de las cosas y, claro, eso disuelve la distinción entre el objeto del intercambio y la forma jurídica del intercambio. Lo que llevó al crecimiento inorgánico de la noción de cosa incorporal en el Derecho chileno fueron razones constitucionales, que empujaron a asumir que la regla del art. 583 era una especificación y no una metáfora, con lo que la noción de "dominio" en el caso de las cosas incorporales se confundió con la de titularidad, para así darle a los derechos la protección que la Constitución da a la propiedad, en particular, protección frente a la retroactividad de la ley. Sobre la confusión entre titularidad y propiedad de cosas incorporales, véanse JANA y Marín (1996), BarRos (1996).)

11 Claro Solar (2013), p. 358, §1729. Nótese que aquí Claro Solar usa la expresión "universalidad jurídica", como lo aclara al principio del párrafo del cual se extraen las expresiones citadas, como sinónimo de "comunidad". 
Obvio como este punto es que la Corte Suprema a veces incurre en esta confusión. En Paredes con Barrera ${ }^{12}$, el actor reivindicaba una cuota ascendiente al $50 \%$ de un predio que era detentado por el demandado. Habiendo obtenido en primera y segunda instancia, la Corte Suprema desechó la acción con base al propio artículo 892:

"En la especie no existe singularidad en el dominio de la cosa, pues el demandante es sólo dueño de acciones y derechos en el bien, sin que sea posible especificar en qué parte de éste recaen esos derechos y acciones. No se da por ende la singularidad, la especificación del bien como se exige por el artículo 889 del Código Civil".

La Corte tiene desde luego razón en que la reivindicación de cuota es imposible conforme al artículo 889, que exige que se trate de un "dueño de una cosa singular". Pero este no puede ser un argumento para desechar una reivindicación de cuota, porque ignora el hecho de que hay una autorización legal expresa para ejercer en este caso la acción (art. 892). Es para evitar este error que es importante recordar que el artículo 892 permite la acción reivindicatoria respecto de cosas que conforme al artículo 889 no son reivindicables. Tiene razón en esto Claro Solar, que podría estar comentando esta sentencia:

"No nos parece, por esto, ajustada a derecho la doctrina de la Corte Suprema según la cual "el precepto del art. 892 sólo se refiere a cuotas indivisas de cosas que salen de la universalidad jurídica, cuyo dominio se singulariza respecto de una persona"13.

Universalidades. Por otro lado, las universalidades no son reivindicables. ¿Qué tipo de universalidades excluye la exigencia del artículo 889? Desde luego, excluye las universalidades de derecho ${ }^{14}$. La única universalidad de derecho que es objeto de un derecho real es la herencia, y para ella la ley contiene una acción especial, la de petición de herencia (art. 1264).

La pregunta interesante, por cierto, es la referida a las universalidades de hecho. Se ha sostenido que las universalidades de hecho no se pueden reivindicar, porque no son cosas singulares ${ }^{15}$. Pero esto no es claro, porque la distinción entre cosas singulares y universalidades de hecho es poco precisa. Si

\footnotetext{
12 Sentencia de la Corte Suprema de 24 de mayo de 2005, rol № 4718-03, comentada en AtriA (2013), pp. 13-73, aquí, pp. 44-45.

${ }^{13}$ Claro Solar (2013), p. 358, §1729 (tomo IX).

14 Alessandri, Somarriva et al. (1998).

15 Alessandri, Somarriva et al.(1998), p. 263. Peñallillo (2006), p. 230.
} 
una universalidad de hecho es una cosa compuesta por otras cosas, es difícil pensar en una cosa corporal que no sea en algún sentido una universalidad. El propio Código Civil se refiere a varias cosas que pueden ser en algún sentido universalidades, en la medida en que están compuestas por cosas que por eso mismo se entienden fungibles.

Para entender este punto puede ser útil repasar someramente la clasificación de las cosas según su cohesión interna que ha explicado Gonzalo Figueroa. Figueroa sostiene que lo que permite que una cosa que está compuesta de otras cosas sea tratada como una unidad es su destinación. La destinación de la cosa lleva a negar la individualidad de sus partes, a tratarlas como piezas que son fungibles en el sentido de que es posible la subrogación real a su respecto:

"Si una cosa está destinada a automóvil..., resulta posible una cierta fungibilidad entre sus partes, la cual admite una cierta subrogación entre ellas. Si el vendedor obligado a entregar un automóvil comprueba que estando aun en su poder le han robado una rueda, podrá adquirir otra rueda para reemplazar la robada y así poder cumplir cabalmente con su obligación. La nueva viene a subrogar la rueda robada, pues existe entre ambas una cierta fungibilidad que se justifica dentro de la unidad "automóvil" de que ambas ruedas son parte"16.

A partir de esta idea rectora, Figueroa distingue bienes simples o singulares (como un caballo, una planta), bienes compuestos que constituyen una unidad física (un reloj, un automóvil, etc.), bienes compuestos que conforman una unidad porque sus partes carecen de valor (como un enjambre de abejas), bienes compuestos formados por partes no unificadas, pero unidas por una destinación común en torno a una cosa principal (las fincas conforme a los arts. 570 y ss., una nave conforme a los arts. 823 y s. CCom), y "bienes formados por una pluralidad de objetos no cohesionados físicamente entre sí, pero unidos por una destinación común que no tiene lugar en torno a una cosa principal"17, como los rebaños (arts. 788, 1123, 1984), los bosques y arbolados (art. 783), los establecimientos comerciales (art. $3^{\circ} \mathrm{N}^{\circ} 2 \mathrm{CCom}$ ). A estas últimas las Ilama "universalidades de hecho".

Ahora bien, si a esta sistematización de las cosas se aplica la regla del artículo 889 ¿qué resulta? No cabe duda de que los caballos, plantas, automóviles, enjambres, fincas y naves son reivindicables. ¿Son reivindicables las universalidades de hecho?

16 Figueroa (1991), p. 56.

17 Figueroa (1991), las caracterizaciones anteriores están tomadas de las pp. 57-58. 
La conclusión sería que las universalidades de hecho son reivindicables, porque son cosas singulares en el sentido del artículo 889. O mejor dicho, son reivindicables en la medida en que sean cosas singulares en el sentido del artículo 889. Lo importante es que lo que la noción de "cosa singular" excluye en principio no es la universalidad de hecho, sino la de derecho ${ }^{18}$.

Las universalidades de hecho son cosas en el mismo sentido que las cosas "singulares". Lo que las diferencia es su funcionalidad económica. Y aquí puede ser útil hacer referencia a qué es aquello en virtud de lo cual las universalidades son tales. Figueroa afirma que es "la voluntad humana"19. Esto es ambiguo. Figueroa lo dice porque va en camino a diferenciar las universalidades de hecho de las de derecho y quiere contrastarlas por referencia a su origen: en un caso la voluntad humana, en el otro la ley. Este es el punto central de la cuestión que estamos tratando ahora: si las universalidades de hecho son tales en virtud del acuerdo de las partes, entonces ellas no son unidades desde el punto de vista del régimen de las cosas, porque el régimen de las cosas atiende al modo en que las cosas aparecen ante el público en general. Entonces habría que decir que la universalidad en tanto cosa individual existe solo para las partes del contrato, no para el resto. La conclusión sería que no es reivindicable, que no está al alcance de las acciones reales, aunque sí personales, en su caso.

¿Es así? ¿Es la universalidad constituida por el acuerdo de las partes? Es claro que puede ser así, que las partes pueden dar unidad a un conjunto de cosas en tanto universalidad de hecho. La pregunta es si el concepto mismo de universalidad de hecho está en este sentido unido al acuerdo contractual, y es por consiguiente un concepto relevante solo en el derecho de obligaciones, no en el régimen de las cosas.

Esta parece ser la tesis de Figueroa:

"La determinación de las partes de dar el carácter de universalidad de hecho será válida sólo entre ellas, y el valor jurídico de este tipo de universalidades no irá más allá del ámbito de la voluntad que les dio origen" ${ }^{20}$.

\footnotetext{
18 Esta es, por cierto, la opinión dominante. Alessandri y Somarriva lo afirman sin dar razones (AlesSANDRI, SOMARRIVA et al. (1957)); Peñailillo sostiene que "la singularidad a excluir las universalidades jurídicas (por la dificultad posesoria) y, sobre todo, a la individualización de la cosa, de modo que, no obstante el término empleado, no parece justificado excluir a las universalidades de hecho (un rebaño, una biblioteca), estando suficientemente individualizado el conjunto" (Peñallillo (2006), pp. 519-520).

19 Figueroa (1991), p. 62.

20 Figueroa (1991), p. 62.
} 
Que esto sea así, dice Figueroa, lo muestra el hecho de que las partes pueden tratar a los bienes que componen las universalidades de hecho como bienes singulares y enajenar, por ejemplo, los libros de una biblioteca unitariamente. Las reglas sobre universalidades en el caso de los rebaños, bosques, etc. son supletorias de la voluntad de las partes. Todo esto es correcto, pero precisamente son supletorias porque la consideración de esas pluralidades de cosas como una unidad no radica solo en la voluntad de las partes, sino en la funcionalidad económica de las mismas. Que el dueño de un automóvil decida venderlo por partes no quiere decir que el concepto de automóvil es supletorio de la voluntad de las partes. El concepto de automóvil, así como el de rebaño, biblioteca o establecimiento de comercio, es parte de la vida.

Si las universalidades de hecho existen como tales en el mundo de la vida y no suponen necesariamente el acuerdo de las partes, entonces son relevantes para el régimen de las cosas y serán, en su caso, cosas tan singulares como cualquier otra. La exigencia de que la cosa sea singular, entonces, solo excluye las universalidades de derecho.

Figueroa: "Solo la universalidad de derecho produce efectos jurídicos, como la existencia de acciones para protegerla" ${ }^{21}$. Esto es incorrecto en el sentido que ya hemos visto: las universalidades de hecho cuentan, en su caso, como cosas singulares. Pero es correcto en el sentido de que solo las universalidades de derecho son tratadas por el derecho como universalidades, porque solo las universalidades de derecho configuran una categoría jurídica reconocida en tanto tal. Por las mismas razones que la ley crea acciones para protegerlas, solo ellas están categorialmente excluidas de la acción que protege el dominio sobre las cosas singulares.

(iii) Cosas apropiables. El dominio al que se refiere el artículo 582 es un derecho subjetivo privado. Las cosas que son susceptibles de ser objeto del dominio son las cosas que la ley declara apropiables. La división fundamental de las cosas (la summa divisio, en palabras del profesor Alejandro Vergara ${ }^{22}$ ) es entre cosas apropiables y cosas no apropiables. Esta distinción se encuentra formulada en el artículo 19 de la Constitución, que asegura:

"Artículo $19 \mathrm{~N}^{\circ}$ 23. La libertad para adquirir el dominio de toda clase de bienes, excepto aquellos que la naturaleza ha hecho comunes a todos los hombres o que deban pertenecer a la Nación toda y la ley lo declare

${ }^{21}$ Figueroa (1991), p. 62.

22 Vergara (2001). 
así. Lo anterior es sin perjuicio de lo prescrito en otros preceptos de esta Constitución".

La regla constitucional sigue a la del Código Civil, que dispone en su artículo 585 que no son apropiables las cosas que la naturaleza ha hecho comunes a todos los hombres. El artículo 589, por su parte, dispone que los bienes nacionales son los que pertenecen a la nación toda.

No es este el lugar para hacer un tratamiento detallado de este tema. Aquí basta decir que los bienes que no son apropiables no son reivindicables y enfatizar que el Código Civil y la Constitución reconocen dos razones diversas en virtud de las cuales los bienes no son apropiables.

La primera es que se trate de bienes que no están sujetos a la jurisdicción estatal. Son las cosas "que la naturaleza ha hecho comunes a todos los hombres". Esto es más claro en el artículo 858 del Código Civil que en el artículo $9^{\circ} \mathrm{N}^{\circ} 23$ de la Constitución, porque el Código Civil agrega que el hecho de que no sean susceptibles de dominio no excluye solo la propiedad privada, sino también la pública: estas cosas "no son susceptibles de dominio, y ninguna nación, corporación o individuo tiene derecho de apropiárselas".

La segunda es que se trate de bienes "que deben pertenecer a la nación toda, y la ley los declare así". Como se sabe, los bienes nacionales pueden ser bienes fiscales o bienes nacionales de uso público. Los bienes inapropiables son solo los segundos. Los bienes fiscales son bienes apropiables, sobre los cuales el Estado tiene derecho de dominio. Los bienes nacionales de uso público no son apropiables y están sustraídos a la posibilidad misma de propiedad privada. Por eso no son reivindicables, y su régimen y protección está fijado por el derecho administrativo ${ }^{23}$.

(iv) Cosas cuya reivindicación no está prohibida. Como las acciones reales no están afectas a un régimen autónomo del derecho real respectivo en cuanto a su procedencia, que la reivindicación esté prohibida significa que en ese caso el dueño ha perdido el dominio ${ }^{24}$. Por eso, la regulación de la

\footnotetext{
${ }^{23}$ Sobre esto, véase ATRIA (2013), pp. 18-23. El profesor Alejandro Vergara ha sostenido que por esto los bienes nacionales de uso público no son bienes del Estado, sino de la nación (VerGara (2001), p. 110). Esto es un error: el Estado es la personificación jurídica de la nación. Por eso si alguien (como en Arriagada con Fisco, sentencia de la Corte Suprema de 18 de abril de 2005, rol № 2846-2003, comentada en ATRIA (2013), pp. 13-17) reclama dominio sobre un bien que es incorrectamente tratado como un bien nacional de uso público (parte de una calle, por ejemplo), el fisco es sujeto pasivo de la acción reivindicatoria. Véase Atria y Salgado (2016), pp. 36-49.

${ }^{24}$ Así, por ejemplo, las reglas de los artículos 1490 y 1491 sobre la oponibilidad al adquirente de la condición resolutoria podrían bien ser tratadas como reglas especiales acerca de la acción reivindicatoria (limitaciones a la posibilidad de reivindicar), pero son tratadas como reglas que permiten
} 
acción reivindicatoria no contiene prohibiciones. Mencionar esta posibilidad es relevante, sin embargo, para no perder de vista la opción que esto significa.

Que todas las cosas que satisfagan los requisitos que ya hemos considerado sean reivindicables se opone a dos soluciones alternativas en sistemas comparados.

La primera es la que justifica la distinción anglosajona entre propiedad real y propiedad personal, entre realty y personalty ${ }^{25}$. La propiedad real (fundamentalmente la propiedad inmueble) estaba protegida con acciones que permitían al dueño exigir la restitución de la cosa, mientras las acciones que protegían la propiedad personal (fundamentalmente mueble) no admitían condena en especie y obligaban al demandado derrotado a pagar el precio de la $\cos ^{26}$.

La segunda es la posibilidad, introducida en el BGB y adoptada por países que han experimentado la influencia alemana (como España, por ejemplo), de la adquisición del dominio a non domino. La adquisición a non domino es una forma de proteger el tráfico jurídico sobre las cosas: el adquirente de buena fe se hace dueño de la cosa (mueble) por tradición aunque el tradente no sea dueño. Esta no es la solución del Código Civil27.

Como advierte Peñailillo, en esta materia Bello siguió el precedente romano, conforme al cual nadie puede transferir derechos que no tiene ${ }^{28}$, y permitió la reivindicación de todas las cosas (muebles e inmuebles, de modo que la distinción inglesa entre propiedad real y propiedad personal no existe) y sin

atribuir el dominio (es decir, como regulación sustantiva del derecho de propiedad). Esto muestra que ambas cosas son lo mismo.

${ }^{25}$ COOKe (2012), pp. 5-6.

26 “Incluso si el demandado decía ‘Esa vaca, Buttercup, que tú tienes, es mía!' el sistema... no le reconoce derecho a obtener la restitución de la vaca. Una sentencia a pagar en dinero será Ilamada 'personal' porque no le da al demandante victorioso un derecho sobre ninguna cosa en particular, sino sólo el derecho de que una persona, el demandado derrotado, pague la cantidad en cuestión". BIRKS (1998), p. 471.

27 Al respecto, véase WesteRMANn et al. (2007), pp. 619-651. Esto es, por cierto, una manera alternativa a la del Código Civil de estabilizar la propiedad. Como en el Código Civil no hay adquisición a non domino, la estabilización de la propiedad debe producirse sobre la base de la usucapión. Por eso Westermann et al. pueden decir, por referencia al derecho alemán, que "la considerable protección del adquirente de buena fe, mediante el parágrafo 932 [que consagra la adquisición a non domino] limita fuertemente la necesidad de una usucapión". WeSTERMANn et al. (2007), pp. 619-651.

${ }^{28}$ Un principio que entre nosotros se enseña como evidente, pero que, como correctamente señala HeRnÁNDEZ GIL (1967), pp. 123 y 126, es "acaso la cumbre del racionalismo jurídico" (p. 123), contra el cual "ha habido margen para una regla que es trasunto de conveniencias y aspiraciones, de buen sentido comunitario, ideal de paz y tolerancia antes que certeza deshumanizada" (p. 126). 
atender a la buena o mala fe del adquirente (lo que excluye la adquisición a non domino).

La protección del tráfico (con mucha menor intensidad que el BGB) se encuentra en la regla del inciso $2^{\circ}$ del artículo 890, que después de disponer que son reivindicables todas las cosas corporales, muebles e inmuebles, agrega:

"Exceptúanse las cosas muebles cuyo poseedor las haya comprado en una feria, tienda, almacén, u otro establecimiento industrial en que se vendan cosas muebles de la misma clase".

"Justificada esta circunstancia, no estará el poseedor obligado a restituir la cosa, si no se le reembolsa lo que haya dado por ella y lo que haya gastado en repararla y mejorarla".

Nótese que esta regla protege el tráfico, pero no contiene un caso de adquisición a non domino. El que compra la cosa mueble en un establecimiento que venda habitualmente cosas de ese tipo no se hace dueño de la cosa por eso, sino es protegido respecto del valor de la cosa. La redacción del artículo 890 da a entender que las cosas a las que se refiere el inciso $2^{\circ}$ no son reivindicables (sería una excepción a la regla del inciso $1^{\circ}$ ), pero el inciso $3^{\circ}$ dispone que sí lo son.

b. Debe dirigirse contra el poseedor. El segundo requisito es que lo que se controvierta mediante la acción reivindicatoria sea el dominio: esto quiere decir que el que la ejerce debe reclamar para sí el dominio sobre la cosa y debe dirigirla en contra de quien incompatiblemente reclame también ser dueño. Pero no basta que el demandado reclame para sí el dominio. Debe estar en una posición jurídica tal que ese reclamo es jurídicamente relevante en tanto tal, y ese es el sentido de la regla del artículo 895: la acción reivindicatoria ha de dirigirse en contra del poseedor.

Es importante destacar especialmente este punto, porque el hecho de que la acción reivindicatoria solo pueda dirigirse contra el poseedor es hoy crecientemente entendido como una exigencia basada en la sola voluntad del legislador ${ }^{29}$. La pretensión reivindicatoria es la de dominio, lo que quiere decir que solo puede ser dirigida en contra de quien pretende dominio y tiene la cosa.

En efecto, lo peculiar de la acción reivindicatoria no es que el que la ejerce invoque su dominio. Después de todo, conforme al artículo 2195 lo mismo debe hacer el que ejerce la acción de precario. Lo peculiar es que el que ejerce la acción invoca su dominio en contra de quien precisamente detenta la cosa reclamando el dominio para sí.

${ }^{29}$ Lathrop (2011), pp. 257-261. 
La exigencia de que la acción reivindicatoria se dirija contra el poseedor, que como hemos visto es necesario dado precisamente que la acción reivindicatoria es una acción de dominio, es cada vez más vista como una exigencia injustificada. En esto parece haber una suerte de confluencia de al menos parte de la doctrina y de la jurisprudencia, aunque no dicho de este modo. Es una de las maneras en que se manifiesta un serio déficit del sistema de acciones del Código Civil. Todas esas manifestaciones son reconducibles a un punto: el sistema de acciones está diseñado sin tomar en consideración la posesión inscrita ${ }^{30}$.

En el sistema del Código Civil, si el dueño es despojado, puede recurrir a los interdictos posesorios para recuperar la posesión de la cosa: el de restitución o restablecimiento, según si el despojo fue o no violento. La posibilidad de usar los interdictos prescribe en un año (seis meses en el caso de la querella de restablecimiento). Al tratar de los interdictos posesorios tendremos que detenernos sobre este plazo de prescripción, porque las acciones reales no pueden extinguirse por vía principal, y esto parece una prescripción extintiva ${ }^{31}$. Lo que ahora importa es lo que ocurre después del año. Al año, la posesión del despojante se consolida, y el despojado ya no puede usar el interdicto porque el derecho reconoce esa posesión. Por consiguiente, si el despojado todavía quiere recuperar la cosa, tendrá que usar la acción reivindicatoria. En este sentido, lo que tenemos que decir respecto de ese año en que el despojado puede usar la querella de restitución es que la ley entiende que la situación es tan inestable que para decidirla no es necesario pronunciarse sobre los derechos alegados por el querellado, y basta mostrar que el modo en que se hizo de la cosa cuenta como despojo. Pero transcurrido el año la posesión de este se ha estabilizado, y ahora la ley lo reconoce poseedor, y por eso al despojado no le basta mostrar que fue despojado: ahora necesita

\footnotetext{
30 No es posible aquí hacer una exposición de lo que se ha llamado la "teoría de la posesión inscrita", cuya formulación canónica está en TRUCCO (1910), pp. 131-155. Lo que importa tener presente es que conforme a ella, la detentación material en términos del artículo 700 no es reconocida como posesión, y quien no tiene ni el corpus ni el animus, pero tiene la cosa inmueble inscrita a su nombre, es poseedor. Nótese que estas dos afirmaciones no son controvertidas por los partidarios de lo que se ha llamado la "inscripción garantía", por lo que son pacíficas. Ante disposiciones como los arts. 728 inc. $2^{\circ}$ y 729 , es indudable que quien tiene la cosa inscrita a su nombre, al menos en casos normales (y dejando de un lado por ahora la idea de "inscripciones de papel"), es poseedor. Y es esto lo que crea el problema que veremos.

${ }^{31}$ Las acciones reales no están sujetas a prescripción extintiva (art. 2517) porque las acciones reales no se extinguen por vía directa, sino solo como consecuencia de la extinción del derecho que protegen o, más estrictamente, por la modificación de la situación jurídica que les da origen: véase Atria (2018) "El sistema de acciones reales, parte especial. La dimensión dinámica del dominio".
} 
mostrar que es dueño, contra el que ahora es poseedor. Esa es precisamente la situación en que procede la acción reivindicatoria.

La acción reivindicatoria y la posesión inscrita. Pero el régimen de posesión inscrita altera esto. Conforme lo declara expresamente el artículo 728 inciso $2^{\circ}$ (y a contrario el art. 729), el que se apodera de una cosa inmueble inscrita no se hace poseedor de ella, y el que es despojado no pierde la posesión. Es decir, la ley no reconoce el ánimo de dueño del que detenta una cosa inmueble inscrita a nombre de otro. Esto, por cierto, no quiere decir que el inscrito no fue despojado, y por eso tendrá sus interdictos de recuperar (restitución y/o restablecimiento, según el caso) ${ }^{32}$. Pero esos interdictos "prescribirán" al año. Pero pasado ese año el despojante seguirá sin ser reconocido como poseedor, por lo que el inscrito no puede ejercer la acción reivindicatoria en su contra. En breve, no tiene acción.

El asunto fue notado por el propio Humberto Trucco, quien sin embargo no le concedió mayor importancia:

"A lo sumo, carecerá de acción reivindicatoria, como consecuencia de lo que llevamos dicho, el dueño que tiene su propiedad inscrita, y esto no es para alarmar á nadie; porque expedito tiene el camino para instaurar una acción nominada o innominada cualquiera contra el detentador de su propiedad.

Podrá, p. ej., instaurar una acción posesoria de restablecimiento si lo han despojado violentamente de la mera tenencia dentro de los seis meses anteriores al reclamo (arts. 916, 921, 926, y 928 del C. C. y art. 700 del C. de Proc. C.).

Si los actos de detentación no son violentos, ó si, siéndolos, han trascurrido más de 6 meses del despojo, deberá instaurar otra acción nominada ó innominada de carácter civil: la de precario del art. 2195 ó la criminal de usurpación (art. 457 del C. Penal)"133.

Nótese la displicencia con que Trucco trata el problema, que se soluciona finalmente invocando una acción innominada cualquiera. Eso podrá ser un buen recurso forense, pero desde el punto de vista de la reconstrucción del sistema de acciones del Código Civil no tiene sentido: es absurdo decir que

\footnotetext{
32 Esto podría ser objetado, y esto deberá quedar pendiente para cuando discutamos los interdictos posesorios en ATRIA (de próxima aparición): "El sistema de acciones reales, parte especial. La dimensión dinámica del dominio". "Despojo" es entendido aquí materialmente, no como un concepto jurídico. Si se entendiera jurídicamente (despojo como privación normativa de la posesión), habría que decir, con Humberto Álvarez, que "no es posible suponer que haya habido despojo, porque la posesión continúa siempre supuesta en quien tiene el título inscrito". Álvarez (1928), p. 19.

33 TRUCCO (1910), p. 145.
} 
el sistema no contempla una acción para el caso del poseedor inscrito que ha perdido la detentación material de su cosa. Es decir, si ese caso debe ser solucionado recurriendo a una acción innominada cualquiera, ¿cuál es el sentido de que haya un sistema de acciones?

Quien mejor ha notado la ironía que en esta materia implica la posesión inscrita ha sido Humberto Álvarez. Álvarez considera el caso en que el vendedor (alter) entrega materialmente la cosa al comprador (ego) y no hace la tradición mediante la inscripción. Veinte años después, imagina Álvarez, alter quiere recobrar la cosa:

"Mi vendedor, poseedor inscrito, más que poseedor inscrito, propietario, no puede entablar en contra mía ni los interdictos posesorios, ni la acción reivindicatoria, atendida a mi confusa calidad que no es mera tenencia, que no es posesión, que no está considerada dentro de nuestras disposiciones legales".

Aceptado, pues, el criterio de la doctrina sustentada por el señor Trucco para considerar que la posesión de bienes raíces está protegida de todo estado de hecho una vez iniciada con la inscripción, tenemos también que reconocer la existencia de una relación desconocida y, por lo tanto, no amparada ni rechazada por el legislador; pero que tiene a su favor, sin embargo, una ventaja superior a todas las protecciones posibles: la invulnerabilidad de toda acción.

En consecuencia, quien -como en el caso en que yo me coloqué- ejercite las facultades correspondientes a un propietario; pero sin ser poseedor, a juicio del señor Trucco, y sin ser mero tenedor, de acuerdo con las disposiciones aludidas de la ley, está en una situación inmejorable ${ }^{34}$.

La posesión inscrita implica que el dueño de un bien inmueble inscrito no tiene acción para recuperarlo cuando ha perdido la tenencia material. La cuestión merece ser considerada con cuidado antes de hacer lo que hace Trucco: buscar con cierto apresuramiento alguna solución. Es claro que alguna solución habrá que encontrar para el dueño en ese caso, porque no es una conclusión aceptable afirmar que simplemente no tiene acción. Pero antes es necesario preguntarse por el sentido de esto.

La paradoja de Ihering: protección que desprotege. La respuesta está en la protección de la posesión, algo sobre lo cual ahora no es posible dedicar toda la atención que merece. Tendrá que bastar aquí lo siguiente. Como es sabido, el fundamento de la posesión posesoria puede ser encontrado en la posesión o fuera de ella. Las primeras son teorías que desde Ihering son denominadas

34 Álvarez (1928), p. 23. 
"absolutas", las segundas "relativas"35. La principal teoría "relativa" es la del propio Ihering, que ha mostrado, correctamente a mi juicio, que la posesión se protege para proteger a la propiedad (una idea que nos volverá a aparecer cuando hablemos de los interdictos y de la acción publiciana). La protección de la posesión es, en términos de Ihering, "un complemento necesario de la protección de la propiedad" 36 .

"Complemento necesario" quiere decir: no hay un régimen propietario sin protección de la posesión. Ihering es agudamente explícito a este respecto: "yo no puedo concebir en la práctica un estado jurídico, fundado únicamente sobre la propiedad romana, con exclusión de la protección posesoria" ${ }^{37}$.

Esto fue ofrecido por Ihering como una explicación de la protección posesoria, pero funciona en ambos sentidos: permite explicar por qué la ley protege la posesión, pero permite anticipar qué es lo que ocurriría si la ley no protegiera la posesión: habría un considerable déficit en la protección del dominio.

Nótese que cuando Ihering dice que la posesión es un "complemento necesario" de la protección del dominio él no está diciendo eso de cualquier cosa que la ley llame "posesión". Lo que es un complemento necesario de la protección del dominio es la protección de la detentación material de las cosas, con ánimo de dueño (art. 700). Y esto es exactamente lo que el Código Civil no protege, tratándose de bienes inmuebles inscritos. Es decir, el Código Civil descansa en el supuesto de que es posible proteger la propiedad inmobiliaria sin proteger la detentación material con ánimo de dueño. Y la conclusión es exactamente la que habría que esperar de tener razón lhering: si no se protege la posesión, hay un severo déficit de protección del dominio. Lo que hemos visto en el caso de la acción reivindicatoria es el caso más irónico de todos: el dueño está tan protegido que el despojo no lo afecta, pero el hecho de que el despojo no lo afecte lo deja sin protección jurídica.

La solución de Álvarez (que ignora la posesión inscrita) es insostenible porque no da cuenta de la regulación contenida en el Código Civil ${ }^{38}$. La de

\footnotetext{
35 IHERING (1892), pp. 2-6.

${ }^{36}$ IHERING (1892), pp. 2-6.

37 IHERING (1892), pp. 2-6.

38 Álvarez (1928), pp. 24-25. Aun cuando el texto de Álvarez es, a mi juicio, lo más agudo que se ha publicado sobre el tema, su tesis general "la inscripción no es requisito, ni garantía, ni prueba de la posesión") no es aceptable. Tampoco es aceptable su solución al problema de las acciones que estamos considerando, y por las mismas razones: porque no da cuenta de las reglas que realmente existen ni del sistema que ellas configuran. Álvarez sostiene que el artículo 724 especifica que si la cosa es de aquellas cuya tradición debe hacerse por inscripción, el que la recibe longa manu adquiere la posesión de la cosa, pero no la posesión regular, en la medida en que invoque un título
} 
Trucco, como ya está dicho, es también absurda. Absurda no porque no tenga razón en que hay que encontrarle al dueño una acción, nominada o innominada, sino porque no puede decirse que el problema "no es para alarmar a nadie" ${ }^{\prime 39}$. Si no es para alarmar a nadie que el sistema de acciones reales del Código Civil simplemente ignore el caso del dueño de un inmueble inscrito que ha sido materialmente despojado, entonces no tiene sentido que haya un régimen de acciones reales. Si no es para alarmar a nadie que la acción reivindicatoria no pueda nunca ser utilizada por el poseedor inscrito, entonces la pregunta es qué sentido tiene que ella exista o qué sentido tiene que deba ser dirigida contra el poseedor.

Y esta última es la conclusión a la que parte de la doctrina y la jurisprudencia han tendido a arribar. Buscando una acción para el dueño, se ha interpretado la regla del artículo 915 como si permitiera una acción reivindicatoria en contra del mero tenedor. Al tratar esta acción y las otras posibles veremos si esta es o no una interpretación adecuada. Por ahora, lo que importa es notar que lo que es necesario es solucionar un problema, lo que tiene dos consecuencias: (i) es importante no olvidar que es un defecto del sistema de acciones lo que origina la búsqueda, por lo que las soluciones no van a ser las más adecuadas, y (ii) hay que estar atento a los problemas que las soluciones puedan a su vez crear.

Daniel Peñailillo cree que, dado que el Código no ha consagrado una acción general restitutoria, la del 915 podría ser interpretada de modo de permitir que operara como tal. Para esto, él sugiere

“conferir al precepto [del art. 915] un alcance extenso... que sea aplicable a todo tenedor que a la época de la demanda no pueda justificar aceptablemente su insistencia en mantener la cosa en su poder" ${ }^{\prime \prime}$.

Peñailillo cree que esta interpretación es necesaria porque no hay una acción general restitutoria. A mi juicio, sin embargo, tal acción no sería necesaria si el sistema de acciones no tuviera el defecto que estamos considerando. Peñailillo describe dos casos en que se hace necesaria tal acción: (i) el de una promesa de compraventa en que se ha autorizado al promitente comprador

traslaticio de dominio, porque no tiene tradición. A mi juicio, esta interpretación es incompatible con la comprensión mínima de lo que para mí es el principio fundamental en materia de posesión registral, que podría denominarse el "principio de integridad del registro". La justificación de esta afirmación no puede emprenderse aquí. Para una explicación no demasiado detallada de este principio, véase ATRIA (En prensa): "El sistema de acciones reales, parte especial. La dimensión dinámica del dominio".

39 Trucco (1910).

40 Peñallillo (2006), pp. 536-537. 
entrar en posesión material, y luego la promesa no se realiza; (ii) ocupantes cuyos contratos emanan de un tercero, que no es el propietario actual.

El primer caso es precisamente, como veremos, el caso en el que procede la acción del artículo 915 interpretada estrictamente, porque se trata de un mero tenedor del propio demandante que pese a haber recibido en virtud de un título de mera tenencia se niega a restituir; el segundo es precisamente el caso problemático, lo que se revela al discutir la acción de precario ${ }^{41}$. Por ahora podemos decir que es problemático porque $\mathrm{A}$, el que reclama ser dueño, dirigirá su acción en contra de B, que tiene la cosa invocando un título de mera tenencia en virtud del cual detenta a nombre de $C$. En este caso es evidente que el auténtico conflicto jurídico no es entre $A$ y $B$, sino entre $A$ y $C$, porque es $C$ quien reclama ser dueño (o ser a su vez mero tenedor de quien sí reclama ser dueño, en el caso del subarriendo u otros estructuralmente similares). La solución no es, por cierto, permitir una acción general que permitiría impugnar oblicuamente la posesión del poseedor, sino la regla del artículo 896, que obliga al mero tenedor de la cosa que se reivindica a declarar el nombre y residencia de la persona a cuyo nombre la tiene. Esto asegura que la acción será dirigida en contra de quien genuinamente tiene la pretensión que está en conflicto con la del dueño.

Pero el profesor Peñailillo va más allá que propiciar una extensión de la acción del artículo 915 para que se desempeñe como una acción general restitutoria. Él cree que la idea de acción civil no tiene sentido:

"Puede sostenerse que el ordenamiento jurídico no exige encuadrar toda pretensión en una determinada acción, nominada, regulada por la ley. Basta que tenga arraigo en un derecho del reclamante que merezca ser tutelado" ${ }^{\prime 2}$.

A mi juicio, esto es un error. Es no entender el sentido de las acciones civiles $^{43}$. Ahora bien, es un error entendible porque el sistema de acciones civiles es notoriamente deficitario, pero el problema no está en la idea de acción civil, sino en el déficit introducido por la posesión inscrita al sistema del Código Civil.

\section{Defensas del demandado}

La posesión del demandado y las posibilidades de defensa de este. El hecho de que la posesión del demandado sea una condición de procedencia de la acción reivindicatoria implica que en un juicio de reivindicación

\footnotetext{
${ }^{41}$ ATRIA (En prensa): "Un integrante honorario del sistema de acciones reales: la acción de precario".

42 Peñallillo (2006), p. 536.

${ }^{43}$ Véase AtriA (En prensa): "El sistema de acciones reales, parte general".
} 
la prueba de la posesión del demandado es carga del actor. Desde luego, esto no implica que en todos los casos deberá haber actividad probatoria del demandante en este sentido, porque eso dependerá del hecho de que el demandado, al defenderse de la acción, reclame o no una pretensión opuesta a la del actor. En el caso típico, el demandado se arrogará el dominio, lo que en principio quiere decir (dado que la acción también supone que detente la cosa) que reclamará para sí la posesión, en la medida en que pretenderá que su detentación actual de la cosa es a título de dueño. Si esta es la defensa del demandado, el demandante no necesitará probar la posesión del demandado, que será entonces un hecho pertinente pero no controvertido. Cuando el demandado se defiende negando su condición de poseedor, es decir, alegando detentar a nombre de otro, la condición bajo la cual detenta el demandado debe ser materia de prueba; si no es poseedor sino mero tenedor de un tercero, deberá concluirse que no es legítimo contradictor, y la acción deberá enderezarse contra el tercero poseedor.

En consecuencia, en la acción reivindicatoria la posesión del demandado no es una defensa del demandado, sino un supuesto de la acción del demandante. Si fuera una defensa del demandado correspondería que, como toda defensa, se basara en hechos que de requerir prueba deben ser probados por quien los alega (art. 1698). Pero como es un supuesto de la acción intentada, es decir, como es una de las cosas que debe ser probada para probar la obligación del demandado de restituir, su prueba corresponde al que ejerce la acción, que alega que el demandado tiene una obligación (la de cesar en su interferencia, restituyendo) ${ }^{44}$.

${ }^{44}$ En lo que es probablemente la discusión más sofisticada disponible de las acciones reales, Jorge Larroucau califica de "paso en falso" el que lleva desde la observación de que en la reivindicación el demandante debe reconocer la condición de poseedor del demandado a la conclusión de que la prueba de la posesión del demandado es carga del demandante, de modo que "el demandado queda al margen de todo lo que se refiere a la prueba del dominio". Larroucau (2014), p. 112. Esta última tesis es incorrecta, sostiene Larroucau, "porque, en primer lugar, el actor asume que otro es el poseedor del bien, pero no 'en el sentido de aceptarlo, sino en el sentido de reconocer que el otro pretende ser dueño' y, en segundo término, porque el Código Civil exige que la acción se dirija en contra del 'actual poseedor' (895) y ello puede ser entendido así porque el actor sólo le reconoce posesión en el momento en que demanda, pero nada dice respecto de los otros momentos de la posesión" (p. 112). Dos comentarios en respuesta: el primero es que Larroucau no se pregunta por qué el Código Civil dispone que la acción reivindicatoria debe dirigirse en contra del poseedor. Como no tiene una respuesta a esa pregunta cree que el demandante puede reconocer al demandado posesión pero solo para unos efectos y no otros, o solo en algunos momentos, pero no en otros. Es extraño que Larroucau no se formule esta pregunta, porque una de sus tesis centrales es que hay que distinguir entre acciones reales que protegen la titularidad del dominio y acciones que protegen su ejercicio (Larroucau (2015): "Acciones reales y estándares de prueba", en lus et Praxis (vol. 21, número 2), pp. 109-160, aquí pp. 109-112). Y la exigencia de que el demandado sea poseedor es una manera de identificar las detentaciones de la cosa que impugnan la titularidad del dominio, porque solo 
En los hechos, por cierto, este supuesto de la acción del demandante puede ser utilizado estratégicamente por el demandado para defenderse de una acción correctamente interpuesta. Esta posibilidad es prevista por la ley en los artículos 896 y 897, que obligan al tenedor a declarar a nombre de quién detenta, bajo apercibimiento de ser declarado responsable de los perjuicios. Esto cubre las posibilidades de acción estratégica del demandado en relación con su detentación de la cosa, que podrían describirse de la siguiente forma:

(a) El demandado es poseedor y lo reconoce. Con esto su alegación no será que tiene la posesión, sino que su detentación de la cosa es a título de dueño, con lo que impugna directamente la pretensión del dueño. La controversia, entonces, solo podrá ser decidida mediante prueba absoluta de dominio.

(b) El demandado es poseedor, pero se hace pasar por mero tenedor. La ley le impone al demandado, si es mero tenedor, la obligación de indicar el nombre y residencia de la persona a nombre de quien detenta (art. 896), de modo que el actor pueda dirigir correctamente su acción. Si el poseedor, en connivencia con un tercero, declara falsamente ser mero tenedor de este, y el actor demanda al tercero, el juicio será fútil, en tanto la sentencia que le imponga al tercero la obligación de restituir no podrá ser cumplida. Este es el caso recíproco del regulado en el artículo 897, y la solución debe ser la misma: el poseedor es responsable de los perjuicios, y si durante el tiempo que duró el juicio adquirió la cosa por prescripción el reivindicante original podrá dirigir en contra de él la reivindicatoria ficta (art. 900) ${ }^{45}$. Para hacer aplicable en este caso el artículo 900 es necesario interpretarlo con algo de

la detentación del poseedor se opone a la pretensión del dueño de ser dueño (quizás queda mejor dicho al revés: solo cuando una detentación niega la pretensión de dominio de todos los demás esa detentación es calificada como "posesión").

45 La acción reivindicatoria ficta tiene dos modalidades: la del art. 898 y la del art. 900. En ambos casos se trata de una acción que ya no es real, sino personal, como consecuencia de que el ejercicio de la acción real de dominio se ha hecho fútil. En el caso del artículo 898, si el poseedor ha dejado de serlo de buena fe, la acción reivindicatoria ficta tiene por objeto el valor efectivamente recibido por el poseedor a cambio de la cosa; si dejó de poseer de mala fe, la indemnización de todo perjuicio. La acción del art. 898 supone que el poseedor ha enajenado la cosa. Dicha enajenación (a título oneroso) es indispensable en el caso del que enajenó de buena fe, porque marca los límites de su responsabilidad. Pero en el caso del que enajenó de mala fe no es necesaria, y por eso es mejor la formulación del art. 900: en este caso basta que el poseedor haya "dejado de poseer", con enajenación o sin ella, porque su responsabilidad no tiene límites, y alcanza a todos los daños causados. Alessandri y Somarriva dicen que el caso del art. 900 no es reivindicatoria ficta, sino reivindicatoria simpliciter: la acción se dirige contra el antiguo poseedor "como si actualmente poseyese, es decir, se le demanda la restitución de la cosa misma, con todos sus accesorios, frutos y demás prestaciones por deterioros de ésta". (Alessandri, Somarriva et al. (1957), p. 809). Pero la cosa demandada aquí operará como un criterio de determinación de la responsabilidad (de su quantum), no como lo efectivamente demandado. 
liberalidad, pero no mucha. El artículo 890 se aplica a quien "ha dejado de poseer", y en nuestro caso el poseedor no ha dejado de poseer, sino que ahora tiene no solo el ius possessionis, sino adicionalmente el ius possidendi. Pero es importante que en este título el poseedor es el que tiene la cosa sin ser dueño, porque este título se refiere al poseedor en contra de quien se dirige la acción reivindicatoria. Y el artículo 890 se refiere al caso en que la acción reivindicatoria se ha hecho imposible. $\mathrm{Si}$, por hecho o culpa suya (es decir, ilícitamente), el poseedor ha hecho imposible la acción reivindicatoria en su contra, está al alcance de la acción reivindicatoria ficta del artículo 890. Por consiguiente, la expresión del artículo 890 debe ser entendida por referencia al ius possessionis y solo al ius possessionis: contra "el poseedor-no-dueño que por hecho o culpa suya ha dejado de ser poseedor-no-dueño" podrá intentarse la acción de dominio como si actualmente fuera poseedor-no-dueño.

Pero ya es dueño, por lo que la condena no podrá ser a la restitución de la cosa; tendrá que ser, como en general ocurre con la reivindicatoria ficta, al precio.

(c) El demandado es mero tenedor y reconoce esto en el juicio. La situación es la misma que en el caso (a), sin el fraude: en virtud de lo dispuesto en el artículo 889, deberá dar el nombre y la residencia de la persona a cuyo nombre tiene la cosa.

(d) El demandado es mero tenedor y, en connivencia con el poseedor, se hace pasar por poseedor. Como está dicho, es el caso recíproco de (b). La finalidad es que la prescripción contra el poseedor no se interrumpa. Como consecuencia de la acción del demandado, el demandante sigue en su contra el juicio y mientras tanto la prescripción corre a favor del poseedor. La solución está en el artículo 897: el demandado es responsable de todos los perjuicios que el engaño haya causado al actor $^{46}$.

\footnotetext{
${ }^{46}$ Entre "algunas de las actitudes que podría adoptar el demandado de reivindicación", y que se refieren, en general, a las situaciones anteriormente tratadas en el texto principal, Peñailillo incorpora una adicional: el demandado "podría sostener que el demandante no es dueño (simplemente lo niega, o agrega que el dueño es cierto tercero)". (Peñallitlo (2006), p. 537). Pero si el demandante no es dueño y el demandado detenta la cosa, hay dos posibilidades: o el demandado pretende ser dueño (y entonces es poseedor) o no pretende ser dueño. Si no pretende ser dueño, o pretende detentar a nombre de un tercero (y entonces es mero tenedor) o no pretende ser mero tenedor de nadie (y entonces es un okupa, quien no pretende título alguno sobre la cosa). En el primero de estos casos, la acción debe enderezarse contra el poseedor; en el segundo, habrá que ver si su no reclamar dominio implica que no tiene la posesión y que es efectivamente un okupa (caso en el cual deberá recurrirse a la acción de precario, porque la situación normal será que en los hechos detenta materialmente como dueño, pero su ánimo de dueño no es reconocido porque la cosa es inscrita), o a pesar de que protesta no tener ánimo de dueño lo tiene en sentido jurídico y es poseedor, caso en el cual procede la acción reivindicatoria contra él.
} 


\section{Reivindicación y otras acciones}

Concurrencia con acciones de protección de la posesión (publiciana, interdictos, precario). La cuestión de la compatibilidad de la acción reivindicatoria con otras acciones de protección del dominio y la posesión es importante precisamente al momento de construir un sistema. Para apreciar debidamente las cuestiones, sin embargo, es necesario hacerlo con el sistema ya desplegado, porque la diferenciación sistemática de sus partes debería ser suficiente para solucionar estas cuestiones. Pero hay un tema en particular en la relación de la acción reivindicatoria con la de demarcación, que como es una acción que no será analizada como parte del sistema de acciones conviene aclarar aquí.

Concurrencia con la acción de demarcación. Esta cuestión no ha sido fácil para la jurisprudencia. Los problemas son también manifestación del defecto fundamental que ya hemos descubierto en el sistema de acciones, que ignora la posesión inscrita.

La acción de demarcación se funda en el derecho reconocido en el artículo 842, que el Código trata como una servidumbre. Aunque hay consenso en que no es una servidumbre ${ }^{47}$, lo que uno podría pensar que justifica su tratamiento como tal es que el de demarcación tiene el régimen de un derecho real, y la acción de demarcación es una acción real: no se extingue por vía principal. La manera de explicar esto no pasa por hacer a la demarcación una servidumbre, sino entendiéndola como una consecuencia de (y entonces sujeta al régimen aplicable a) el derecho de dominio mismo.

En todo caso, en lo que nos interesa, se trata de una acción del propietario orientada a "que se fijen los límites que lo separan de los predios colindantes" (art. 842). Esto en principio ofrece un criterio de diferenciación entre esta acción y la reivindicatoria:

"La de demarcación persigue fijar judicialmente los límites dentro de los

cuales se extiende una propiedad y la separan de otras; la reivindicatoria tiende a obtener la restitución de un terreno cuyo dominio pretende el demandante y que está en posesión del demandado" ${ }^{48}$.

Pero esta delimitación puede hacerse dudosa cuando al demarcar un predio se le atribuye un área que antes se le atribuía al predio vecino o que permanecía en una zona de indefinición. Cuando ese es el caso, ¿se está reivindicando esa parte del predio o se está demarcando el deslinde? En los

\footnotetext{
47 Peñalilllo (2006), p. 537.

${ }^{48}$ Alessandri, Somarriva et al. (1957), p. 712.
} 
hechos, es perfectamente posible que se esté haciendo ambas cosas. Entonces, ¿qué acción procede?

Alessandri y Somarriva no se pronuncian, más allá de explicar qué es lo que ha decidido la Corte Suprema; al hacerlo, sin embargo, formulan un criterio que puede ser de utilidad:

"La Corte Suprema ha resuelto que procede la acción de demarcación si ninguno de los vecinos posee el suelo en cuestión con ánimo de señor o dueño; de lo contrario, para obtener que se prive a uno de la posesión y se entregue al otro, hay que recurrir necesariamente a la acción reivindicatoria" ${ }^{49}$.

La misma solución es defendida por Peñailillo:

"Si la zona conflictiva no es poseída efectivamente (mediante actos posesorios materiales, ostensibles) por ninguno de los contendores, procede la demarcación; por el contrario, si ese territorio está siendo poseído por otro (el vecino) y se pretende la restitución, lo procedente es la reivindicatoria" ${ }^{\prime 50}$.

Es curioso que ni Alessandri y Somarriva ni Peñailillo hagan referencia alguna a la posesión inscrita al diferenciar la acción reivindicatoria de la de demarcación. Pero parece claro qué es lo que habría que decir: si la demarcación procede siempre que no haya una zona conflictiva poseída por ambos, y si la posesión es inscripción, la demarcación procederá en todos los casos en los que no haya superposición de inscripciones y tendrá por objeto demarcar materialmente los deslindes fijados en los títulos. Si al hacer el intento de demarcación queda en evidencia que hay en los títulos superposición de inscripciones, entonces la cuestión no podrá ser solucionada mediante la demarcación y deberá discutirse sobre los títulos, en un juicio de reivindicación.

Quizás los autores mencionados no aplican su criterio al caso normal de predios inscritos porque dicha aplicación les parece suficientemente obvia. Si fuera así, habría aquí cierta ironía, porque este es precisamente el punto que es discutido hoy por la jurisprudencia. Conforme a lo que ya puede denominarse una línea jurisprudencial que cuenta hoy con el respaldo de la Corte Suprema ${ }^{51}$, en relación con la acción de cerramiento y demarcación,

49 Alessandri, Somarriva et al. (1957), p. 712.

50 Peñallillo (2006), p. 496.

51 Lo que ha sido destacado por BARCiA (En prensa): "La concurrencia de acciones reales a la luz de la jurisprudencia de la Corte Suprema en torno a la posesión material", en Revista de Derecho de la 
reiteradamente se ha sostenido que tiene por objeto únicamente que se fijen los límites o deslindes que separan el predio de quien ejerce la acción de los inmuebles colindantes, realizándose tal fijación tanto de un modo jurídico, es decir, orientado a reconocer la línea divisoria, como de una manera material, esto es, a través de la instalación de los hitos apropiados. En otros términos, no puede existir discusión acerca de la cabida de los predios vecinos, pues, en ese evento, muta la pretensión hacia acciones diversas, sean posesorias o reivindicatorias. Por ende, los requisitos que hacen concurrente a una acción como la de que se trata están constituidos por la presencia de predios distintos, la vecindad entre ellos y que las partes concuerden en sus cabidas y títulos ${ }^{52}$.

Por consiguiente, la Corte Suprema hoy tiende a decidir que si de hecho hay un deslinde visible (una cerca, un muro, etc.) la acción de demarcación es improcedente: porque o ese deslinde es correcto, y entonces no hay razón para ejercer la acción de demarcación, o ese deslinde es incorrecto, y entonces uno de los vecinos al menos posee una parte del predio del otro, $y$ en ese caso lo que procede es la acción reivindicatoria.

Nótese cómo la exigencia original de Alessandri y Somarriva, que ninguno de los vecinos posea el área en cuestión, se transforma en que ninguno de los vecinos posea materialmente. Y de ahí hay un paso a poner una condición que hace irrelevante a la acción de demarcación: que no haya controversia sobre el deslinde, "que las partes concuerden en sus cabidas y títulos". ¡Pero si las partes concuerdan, evidentemente no será necesario un procedimiento judicial! Esto muestra que el criterio de Alessandri y Somarriva y Peñailillo puede ser mejorado. No se trata de que ninguno posea, se trata de que no haya una controversia sobre el dominio jurídicamente relevante. Puede en los hechos haber controversia, pero si no hay una controversia jurídicamente relevante lo que procede no es decidir mediante la acción reivindicatoria esa controversia, sino ignorarla y simplemente delimitar los predios.

Y este, por cierto, es el caso cuando se trata de la posesión inscrita. Porque la posesión material no es posesión cuando se trata de un predio inscrito. Si el predio inscrito a nombre de A deslinda con el inscrito a nombre de B y en las inscripciones no hay superposición, entonces cada uno posee su predio. El hecho de que haya una demarcación incorrecta en virtud de la cual una parte del predio de A queda en el lado de B no implica que B tenga posesión de dicho retazo. Si de hecho, B reclama ser dueño de esa parte del predio, habrá en sentido puramente fáctico una controversia entre A y B. Pero esa

Universidad Católica del Norte.

${ }^{52}$ Cárdenas con Báez (Corte Suprema, rol № 178-14, 4 de junio de 2014), c. 6. 
controversia no es reconocida por el derecho: habrá que decir que al erigir el cerco incorrectamente, $B$ se apoderó de una parte del predio de $A$, en el sentido preciso en el que el artículo 728 inciso $2^{\circ}$ dispone que el apoderamiento material de un predio inscrito no afecta la posesión. Como no la afecta, jurídicamente lo que procede es la demarcación, es decir, la erección en el terreno mismo de un cerco o deslinde visible que separe los dos predios.

Si los títulos mostraran superposición, entonces habría un problema de atribución del dominio jurídicamente relevante. En ese caso la discusión no es sobre la demarcación, sino sobre cuál es la línea de cuya demarcación se trata; no es sobre construir un deslinde aparente sobre el terreno, sino sobre cuáles son los límites de cada predio; no es un problema de apariencia, es un problema de títulos que dan cuenta de pretensiones jurídicamente reconocibles de dominio. Y para resolver los problemas de pretensiones jurídicamente reconocibles de dominio pero incompatibles entre sí es necesario recurrir a la acción reivindicatoria.

Al negar la acción de demarcación cuando hay deslindes visibles, los tribunales están en los hechos ignorando la posesión inscrita y reconociendo como jurídicamente relevante la pretensión de dominio sobre un inmueble inscrito de quien solo posee materialmente. Más adelante veremos si una estrategia de este tipo es la mejor manera de solucionar los defectos que encontraremos en el sistema de acciones, pero por ahora hay que decir: si en este caso no procede la acción de demarcación, entonces procede la reivindicatoria. Pero el que detenta materialmente un bien inscrito no es poseedor, por lo que no es sujeto pasivo de la acción reivindicatoria. Si los tribunales aceptan en este caso la acción reivindicatoria, es porque reconocen la pretensión de dominio del que detenta materialmente, y si la reconocen es porque posee. Y si posee, conforme al artículo 2510 se hará dueño a los diez años. Los tribunales no han llegado tan lejos y han entendido que posee para el solo efecto de interponer la acción reivindicatoria. Esto implica que hay dos conceptos de posesión. En algún sentido, no hay nada nuevo bajo el sol. Es la versión chilena del surgimiento de la bonorum possessio en el derecho romano, o de la protección posesoria en general.

Pero eso no quiere decir que no sea problemático. Aunque la cuestión no puede ser tratada en detalle aquí, la posesión cumple en el derecho chileno una función estabilizadora del dominio: todo el que ha poseído por diez años es dueño, en todo caso, siempre (art. 2510, la regla de clausura del régimen de las cosas). Esto es necesario para que probar posesión por diez años sea probar irrefutablemente la propiedad. La introducción de formas posesorias que no llevan al dominio mina esta regla de clausura, y con eso desestabiliza el régimen de las cosas. 
O al menos lo desestabilizaría si fuera un régimen que descansara en el derecho, en vez de hacerlo en vínculos tradicionales. Porque hay que tener una respuesta a la observación de Victorio Pescio, de que a pesar de toda la controversia sobre la posesión inscrita (y los problemas del sistema de acciones, y las reglas de regularización, etc.),

es admirable que discrepancia tan profunda e irreconciliable en materia tan delicada y trascendental no haya tenido, sin embargo, repercusiones catastróficas en la vida económica del país ${ }^{53}$.

Compatibilidad de la acción reivindicatoria con otras acciones (acción de nulidad, acción resolutoria). Conforme al artículo 1689, "la nulidad judicialmente declarada da acción reivindicatoria en contra de terceros poseedores". Esa regla parece implicar un determinado orden de procedencia tratándose de un contrato traslaticio de dominio que ya ha sido cumplido: primero ha de obtenerse la declaración de nulidad del contrato, y solo entonces intentarse la acción reivindicatoria en contra de terceros poseedores.

Una solución como esta tiene un problema, sin embargo: la interposición de una acción de nulidad, o incluso reivindicatoria, no afecta el estatus de poseedor de quien sea poseedor, que entonces lo seguirá siendo durante el juicio (art. 902 CC). Si el poseedor es además el demandado, esto no es problemático, porque, aunque durante el juicio tendrá la posesión de la cosa, no correrá el plazo de prescripción a su favor, que se halla interrumpido en virtud de la notificación de la demanda (art. 2503). Pero si se ejerce la acción de nulidad en contra de quien había sido parte en el contrato de cuya nulidad se trata esperando de ese modo obtener una declaración que permitirá en su momento interponer la acción reivindicatoria en contra del adquirente del demandado de nulidad (el tercero poseedor en el caso del art. 1689), la cuestión es significativamente distinta. El tercero poseedor seguirá poseyendo durante el juicio de nulidad, pero como él no es parte del contrato cuya nulidad se pide él no necesita ser parte del juicio de nulidad. Y adicionalmente, podría incluso decirse que aunque lo sea, el hecho de haber un juicio de nulidad no es suficiente para producir la interrupción civil de la prescripción, porque esta solo se produce cuando el que se pretende dueño invoca su condición de dueño contra el poseedor para que este restituya, y esa no es la situación cuando lo que se ha entablado es una acción de nulidad en contra de un antecesor en el dominio del poseedor actual. Por consiguiente, el problema subsiste: el tercero poseedor no ve interrumpida su prescripción durante el

53 PeSCIO (1978), p. 348. 
juicio de nulidad, y eso entonces puede implicar que cuando la nulidad sea declarada ya no esté disponible la acción reivindicatoria, porque en el intertanto el tercero habrá adquirido el dominio por prescripción adquisitiva. Este es, después de todo, el caso más evidente en que se aplica la limitación a la regla del artículo 1689 que ese mismo artículo anuncia: "sin perjuicio de las excepciones legales".

La solución es relativamente simple y está contenida en el artículo 18 del Código de Procedimiento Civil, que permite al demandante en un caso como este interponer, conjuntamente y en el mismo juicio, las dos acciones: la de nulidad en contra de su contraparte en el contrato original y la reivindicatoria en contra del tercero poseedor ${ }^{54}$. La procedencia de la acción reivindicatoria, desde luego, queda condicionada a la declaración de nulidad, pero como esta es retroactiva no hay razón por la cual no puedan presentarse las dos al mismo tiempo. Al notificar la acción reivindicatoria al tercero poseedor, la prescripción que corre en beneficio de este queda interrumpida y habrá entonces que esperar las resultas del juicio. Aquí el tercero poseedor no es parte del juicio de nulidad (no podría serlo, porque no es legitimado pasivo de la acción de nulidad), aunque sí lo es del de reivindicación.

La situación es la misma en relación con la acción resolutoria ${ }^{55}$, aunque aquí es importante recordar lo ya observado: la acción reivindicatoria no pasa contra terceros de buena fe (arts. 1490 y 1491).

\section{Prueba relativa de mejor derecho}

Prueba del dominio, relativa y absoluta. La acción reivindicatoria supone probar dominio. Y la prueba del dominio que exige la acción reivindicatoria no es cualquier prueba; es la que se denomina probatio diabolica. Peñailillo:

"Para acreditarlo, tiene importancia determinar si el reivindicante adquirió la cosa por un modo originario o derivativo. En la primera situación, le bastará probar los hechos que constituyeron ese modo originario. Pero si adquirió por un modo derivativo, como la tradición (que será lo más frecuente), no basta con probar que ese modo se configuró a favor del que se pretende dueño (si se trata de un mueble, que se le entregó con ánimo de transferírsele el dominio o, si se trata de un inmueble, que tiene inscripción a su nombre), porque quedará la interrogante de si el

\footnotetext{
${ }^{54}$ La misma solución, en AlESSANDRI, SOMARRIVA et al. (1957), p. 776 (aunque invocando solo razones de "economía procesal", lo que es correcto cuando el poseedor es la parte del contrato que se reclama nulo, pero no cuando esta ha enajenado la cosa, en virtud de la regla del art. 2503).

55 Alessandri, Somarriva et al. (1957), p. 776.
} 
antecesor, a su vez, tenía o no el dominio (recordando que 'nadie da lo que no tiene', nemo dat quod non habet) ${ }^{\prime \prime 56}$.

Obsérvese que la situación es más grave de lo indicado por Peñailillo. Él dice que si se alega la adquisición del dominio por un modo originario "le bastará probar los hechos que configuran ese modo originario". Pero aquí hay que proceder con más cuidado. Los modos originarios son accesión, ocupación y prescripción. Si invoca la accesión, deberá probar el dominio de la cosa principal, y eso reproducirá el problema de la probatio diabolica; y si invoca la ocupación, deberá probar (a) la aprehensión de la cosa y (b) que ella carecía de dueño, lo que es una prueba negativa de dominio, incluso más difícil que la prueba del dominio (se trataría de una probatio diabolica... ¡ ide un hecho negativo!). Por consiguiente, en los hechos (que no en la teoría) la única manera de probar el dominio es mediante la posesión ${ }^{57}$. La posesión y su consecuencia, la usucapión, hacen que la probatio diabolica sea menos diabólica, en la medida en que todo lo que hay que probar es detentación con ánimo de dueño por 10 años (la regla del art. 2510 CC es la regla de clausura del régimen de las cosas y permite afirmar que no es jurídicamente posible que quien ha poseído una cosa por 10 años no sea dueño $\left.{ }^{58}\right)$. Y a esta facilitación hay que sumar el Registro del Conservador de Bienes Raíces, cuyo sentido es hacer trivial lo que en su momento fue "diabólico" (la idea original era que, como observara Luis Claro Solar, "el día en que todos los bienes raíces se hallen inscritos, esa dificultad habrá desaparecido casi por completo" $\left.{ }^{59}\right)$. Por eso no es correcto oponer sin más la prueba de la propiedad a la prueba de la posesión ${ }^{60}$, al menos en el espíritu original del sistema: si toda posesión de al menos 10 años hiciera siempre, indefectiblemente, dueño al poseedor, y si las posesiones son agregables, entonces 10 años después de la primera inscripción la distinción entre prueba

\footnotetext{
56 Peñallillo (2006), p. 527.

57 ATRIA 2017. "Un integrante honorario del sistema de acciones reales: la acción de precario".

${ }^{58}$ El sistema solo funciona si la posesión es caracterizada de modo puramente fáctico, de manera que pueda decirse: si alguien de hecho poseyó la cosa por diez años, entonces es dueño. Si el concepto de posesión se normativiza, entonces todo se empieza a hacer exponencialmente más complejo. $\mathrm{Si}$, por ejemplo, hay posesiones inútiles, entonces no bastará probar que alguien ha sido poseedor, será necesario probar que su posesión no era inútil (discutiremos el efecto de la violencia sobre la posesión al hablar de la querella de restablecimiento, en ATRIA (En prensa): "El sistema de acciones reales, parte especial. La dimensión dinámica del dominio"). A mi juicio, la estabilidad del régimen de las cosas exige que uno pueda decir, con seguridad, que toda posesión lleva, siempre y en todos los casos, al dominio.

${ }^{59}$ Claro Solar (2013), p. 361, §1733.

${ }^{60}$ Como lo hace Larroucau (2014), p. 116.
} 
de la posesión y prueba de dominio sería puramente teórica. Y la prueba del dominio no solo dejaría de ser "diabólica", sino pasaría a ser tan simple como producir un certificado.

Ahora, cuando de lo que se trata es de la prueba, lo que es necesario está fijado por consideraciones pragmáticas. ¿Soluciona esto el problema de la probatio diabolica o lo transforma al menos en un problema que habrá que evaluar de caso a caso? En alguna medida lo soluciona. La acción de precario, por ejemplo, la tiene el dueño, pero para probar su dominio el actor puede descansar en la presunción del inciso $2^{\circ}$ del artículo 700, por lo que no necesita probar más que su posesión. Pero esto no es así en la acción reivindicatoria, en que el dominio tendrá que ser probado por el actor sin recurrir a la presunción. Ello porque el demandado debe tener la posesión, y por eso la presunción favorecerá al demandado, por lo que evidentemente el demandante no podrá aprovecharse de ella. Después de todo, la situación de la reivindicatoria es precisamente que el actor no es poseedor.

Es importante aquí ser lo más preciso posible al identificar lo que es especial acerca de la acción reivindicatoria y lo que es general acerca de la carga de la prueba. Es aplicación de la regla general del artículo 1698 que el demandante deba probar los fundamentos de su acción en el sentido de que si no logra probarlos el demandado, sin necesidad de realizar actividad probatoria alguna, obtendrá sentencia favorable. Por consiguiente, no es necesario apelar al inciso $2^{\circ}$ del artículo 700 para concluir que el demandante debe probar su dominio en el sentido de que, faltando esa prueba, el demandado vencerá aun si permanece en total inactividad. En este sentido, el de la carga de la prueba, la presunción del inciso $2^{\circ}$ del artículo 700 no produce efecto alguno.

Pero lo anterior no quiere decir que no haya una dificultad especial para el demandante de reivindicación. Lo que ocurre es que, como hemos visto, probar directamente el dominio es difícil. El Código Civil facilita la prueba del dominio en dos pasos: primero permite probar el dominio mediante la prueba de la posesión, y luego pretende facilitar la prueba de la posesión con la inscripción. Dados estos dos pasos, lo que era una prueba diabólica deviene una prueba trivial (o al menos esa es la pretensión). Pero en el caso de la reivindicatoria, que ha de dirigirse contra el poseedor, es el demandado el que estará en posición de probar su dominio mediante la prueba de la posesión. Al demandante, entonces, le corresponderá probar el dominio directamente, no a través de la posesión. Esto es lo que hace la vida difícil para el demandante.

¿Puede uno tratar esta dificultad para el demandante como algo superfluo, una consecuencia de alguna regla mal formulada que para facilitar la 
protección del dominio podría ser corregida? La respuesta es que no hay mucho espacio para eso, porque es consecuencia del sentido mismo de la reivindicatoria: que ella es el modo de discutir la titularidad del dominio cuando dicha titularidad es impugnada. Ante quien reclama ser dueño de una cosa y la tiene, lo único que es suficiente es probar dominio sobre la cosa. La acción reivindicatoria, por eso, supone que el actor ha de probar no que tiene mejor derecho a la cosa que el demandado, sino que tiene mejor derecho que todos, porque es el dueño ${ }^{61}$. Esta es la razón por la que la acción reivindicatoria, que exige reconocer al demandado la posesión de la cosa, deja al actor en una "posición peligrosa"62.

Ahora, elevar de este modo la exigencia para el dueño dificulta el acceso a la protección judicial de su derecho. Y el sistema de acciones pretende facilitar todo lo que sea posible el acceso a esa protección, no formulando más exigencias que las necesarias como condición para acceder a ella. Y el primer ajuste consiste en dispensar al actor de la prueba absoluta de dominio cuando la prueba relativa es suficiente: si es suficiente para decidir la controversia entre el actor y el demandado mostrar que el demandante tiene mejor derecho a la cosa que el demandado, no tiene sentido obligar al primero a probar que tiene mejor derecho que el demandado, con el que está en juicio, y que todo el resto de la humanidad, con quien no lo está. El nombre habitual para la acción reivindicatoria en este caso es el de "acción publiciana".

\section{La acción publiciana}

Una acción que es entendida al revés. No es la anterior la manera en que la acción publiciana normalmente se explica, porque la reflexión es confundida por la forma del derecho. La doctrina suele enfatizar que la acción

\footnotetext{
${ }^{61}$ Por supuesto, la prueba de que tiene mejor derecho que todos no afecta a todos, porque por razones procesales de relatividad de las sentencias la decisión judicial no afectará a terceros; lo dicho en el texto principal no se refiere a los efectos de la sentencia judicial, sino al contenido de la pretensión que el actor debe entablar: su pretensión no es que frente a este demandado particular tiene mejor derecho, sino que la razón por la que tiene mejor derecho en contra de él es porque tiene el mejor derecho concebible sobre la cosa.

${ }^{62}$ Peñailitlo (2006), p. 526. Peñailillo dice que el peligro se debe a que el demandado podrá, si se cumplen las condiciones, alegar la prescripción (p. 526). Pero esto tiene que ver con las pretensiones sustantivas de las partes, no con el peligro de la acción reivindicatoria. El peligro es que, al reconocer al demandado posesión, ha elevado notoriamente el estándar de prueba al que él mismo, el actor, deberá someterse: lo ha elevado a la probatio diabolica.
} 
publiciana es una acción diferente de la acción reivindicatoria ${ }^{63}$, porque no la tiene el dueño, sino el poseedor regular. Y la tiene no en contra de cualquier poseedor, sino solo en contra del que posea con peor derecho. Entonces la acción publiciana es entendida como una acción cuya "misión específica" es proteger la posesión regular ${ }^{64}$. Luis Claro Solar llega a decir que es una acción "reivindicadora de la posesión" $(!)^{65}$. Su relevancia para la protección del dominio sería solo indirecta:

"La acción publiciana resulta útil no sólo para defender directamente la posesión regular de la cosa, sino indirectamente el dominio. Sabido es que la prueba de éste es muy difícil en muchos casos; entonces el propietario, ejerciendo la acción publiciana, puede alivianar su carga probatoria, limitándose a invocar y probar su mejor derecho a poseer frente al adversario. De esta manera logra el mismo efecto práctico que con la acción reivindicatoria, la devolución de la cosa.

Los tribunales chilenos, considerando fines prácticos, han estimado que el actor que hace uso de la acción reivindicatoria debe estimarse que implícitamente invoca también la acción publiciana si no logra probar su dominio sobre la cosa reivindicada, pero sí el mejor derecho a poseer que el contendor" ${ }^{\prime \prime 6}$.

Esto es entender las cosas precisamente al revés: es asumir que (a) lo que realmente importa acerca de la acción publiciana es la protección de algo distinto de la propiedad, la posesión regular, por razones de equidad y presunción de dominio. Y ya que la acción publiciana existe, (b) el dueño puede aprovecharse de ella. Y aunque no es en rigor correcto (de otro modo la explicación que viene sería innecesaria), pero considerando cuestiones de fines puramente prácticos (economía procesal, etc.), (c) los tribunales entienden que cuando se ejerce la acción reivindicatoria se está ejerciendo implícitamente la publiciana, si es el caso que el demandante logra probar su mejor derecho que el demandado, pero no su dominio absoluto.

\footnotetext{
${ }^{63}$ A pesar de que el Código es explícito en el sentido contrario: "se concede la misma acción...", dispone el art. 894. El tenor literal nunca es un argumento definitivo, pero no puede ser pura y simplemente ignorado. El texto del artículo 894 debe implicar que hay una buena razón para explorar la idea de que la acción publiciana es la misma acción reivindicatoria. Peñailillo dice que la expresión del art. 894 "no puede entenderse tan literalmente porque este sujeto activo no tiene el dominio" (PeÑallillo (2006), p. 526), lo que lo lleva a adherir a la lectura invertida, que es tradicional y que se explica a continuación en el texto principal.

${ }^{64}$ AlesSandri, Somarriva et al. (1957), p. 772.

${ }^{65}$ Claro Solar (2013), p. 369, §1743.

${ }^{66}$ Alessandri, Somarriva et al. (1957), p. 792.
} 
Cada una de estas afirmaciones es en sus términos correcta, pero el orden en que ellas se hacen debe ser invertido y de ese modo aparece el sentido de la acción publiciana, que no es más que rebajar el umbral de procedencia de la acción reivindicatoria cuando ese umbral más bajo sea suficiente. Por eso conviene comenzar por el final: cuando se ejerce la acción reivindicatoria, pero el demandante no logra probar absolutamente su dominio, pero sí que tiene mejor derecho que el demandado, "debe estimarse que el demandante implícitamente ha invocado la acción publiciana" ${ }^{67}$. Por esto es importante que el artículo 894 especifique que se trata de la misma acción. Entonces podemos prescindir de la estimación acerca de lo que ha sido implícitamente invocado: para la procedencia de la acción reivindicatoria es en principio necesario probar el dominio en términos absolutos, pero si es el caso que probarlo relativamente (=probar tener mejor derecho que el demandado) es posible y suficiente, entonces eso basta para que la acción sea acogida. Los "fines prácticos" a los que hacen referencia Alessandri y Somarriva no son los que llevan a los tribunales a hacer esto, sino los que llevaron al surgimiento y reconocimiento de la acción publiciana. No es que el dueño pueda aprovecharse de la acción publiciana, es que la acción publiciana es para el dueño, en el sentido de que ella existe porque de ese modo el dueño puede acceder, cuando corresponda, a la protección de su derecho sin tener que probar lo más difícil, si es que lo más fácil es suficiente.

Por consiguiente, no es necesario elaborar alambicadas teorías para responder qué es lo protegido por la acción publiciana. En la explicación invertida tradicional, la pregunta se plantea porque como la acción publiciana no protege (sino indirectamente y por rebote) al dominio, su fundamento tiene que estar en la protección de algo distinto. "En estos términos surge la interrogante de qué es lo protegido"68. Parece razonable decir: la posesión regular, porque después de todo es el poseedor regular el que tiene esta acción. Pero entonces el problema es que cuando la acción surge ya no hay nada que proteger, porque si el poseedor regular ejerce la acción publiciana es porque ha perdido la posesión, y si ha perdido la posesión entonces es claro que ya no es poseedor regular. Algunos a partir de esto dicen que el artículo 894 exige para ejercer la posesión regular que el demandante sea dueño (que ya haya cumplido el plazo de prescripción ordinaria para acceder al dominio). Pero si esta explicación es desechada (como debe serlo, porque es absurdo exigir para que proceda la acción publiciana que proceda la acción reivindicatoria) pareciera que hay que decir que la posesión regular, entonces, es

67 Peñailillo (2006), p. 235.

68 Peñallillo (2006), p. 235. 
una condición que es resistente a la pérdida fáctica de la posesión, lo que es también absurdo, porque la posesión es un hecho.

¡O quizás la posesión no es, después de todo, un hecho! Y entonces a partir de esto comienza la teorización sobre la posesión como derecho o como hecho con consecuencias jurídicas, etc. Toda esta sobreteorización es gratuita, es causada por una comprensión invertida del problema inducida, a su vez, por una comprensión formalista del derecho.

La finalidad de la acción publiciana no es proteger la posesión regular, sino el dominio. Esto se logra por la vía de reducir las condiciones de procedencia de la acción reivindicatoria, cuando eso sea suficiente. Por consiguiente, lo protegido es el dominio, no la posesión. Pero del hecho de que lo protegido por la acción publiciana sea el dominio no se sigue en absoluto que solo el dueño la tenga. La protección al poseedor regular que no es dueño, que en la explicación tradicional es la finalidad principal de la acción publiciana, es aquí un exceso indeseado pero inevitable. Indeseado, y por eso no es necesario encontrar una fundamentación para el deseo legislativo de proteger al que fue poseedor regular, pero ya no lo es porque perdió la posesión; pero inevitable, porque la única manera de evitar dar protección al poseedor regular que no es dueño es decir que para la procedencia de la acción es necesario probar no solo la posesión regular, sino el dominio y con eso estaríamos de vuelta en la acción reivindicatoria, con la exagerada exigencia de prueba para el dueño y la consecuente dificultad adicional e injustificada en el acceso a la protección ${ }^{69}$.

La noción de mejor derecho. ¿Qué quiere decir que el demandante tenga mejor derecho que el demandado? Esta cuestión no suele ser discutida, y se asume que es una noción suficientemente transparente en su contenido. Alessandri y Somarriva, por ejemplo, se limitan a decir que la acción publiciana procede "contra aquellos que tienen, como poseedores, una condición inferior, un derecho a poseer más débil" ${ }^{\prime 70}$. Pero la idea de derechos más o menos débiles es en general ajena al Código Civil (particularmente considerando que el nombre habitual para el "derecho a poseer" es... "propiedad"): o el poseedor tiene derecho a poseer o no tiene. No puede haber dos personas

\footnotetext{
${ }^{69}$ Esta es una nueva dimensión de lo que ya hemos denominado "la paradoja de Ihering". Comentando la situación, que es posible también en el Derecho chileno atendido lo dispuesto en el art. 923, en la que el poseedor vence al dueño en un juicio posesorio, Ihering explica: "De este modo es posible que el no propietario triunfe en el posesorio contra el propietario. La institución hecha para éste se resuelve en su contra. Pero no sucumbe, porque la reivindicación le proporciona el modo de dar fin en cualquier momento a la posesión provisionalmente protegida de su adversario. Esos efectos que exceden del fin legal de las instituciones jurídicas, son, hay que reconocerlo, incorrecciones que el legislador debe aceptar sin remedio; es como la lluvia, que riega lo mismo a los que la necesitan que a los que no la necesitan". IHERING (1974).

70 Alessandri, Somarriva et al. (1957), p. 791.
} 
con derechos independientes a poseer. La noción de "mejor derecho", por eso, debe ser considerada con cuidado.

Para hacerlo, tenemos que comenzar desde el dominio, no de la posesión. Ello porque después de todo, la idea misma de "derecho a poseer" (ius possidendi, diferenciado del estatuto jurídico aplicable al que efectivamente posee, ius possessionis) se identifica al menos con parte del contenido del dominio.

El derecho de dominio puede representarse mediante una línea que une el punto de origen y el punto de extinción:

Figura I

La propiedad como derecho subjetivo

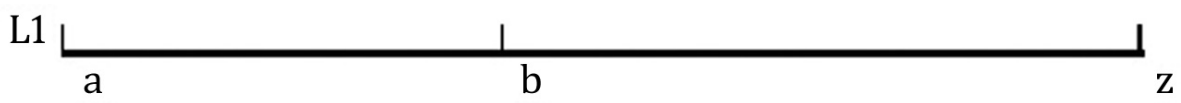

Donde (a), naturalmente, identifica el modo originario de adquisición, (b) un modo de traslación o transmisión y (z) la extinción del dominio. Los dos primeros puntos se analizan en términos de modos de adquirir, y la diferencia entre ellos justifica la distinción entre modos originarios (a) y derivativos (b). El punto final (z) es una evento apto para extinguir el dominio. Como el dominio es un derecho perpetuo (y en notoria diferencia con las obligaciones), los modos de extinción del dominio carecen, por regla general, de interés dogmático ${ }^{71}$.

Como la propiedad es un derecho sobre cosas, y parte de su contenido es el ius possidendi, la situación normal será que el que es titular del dominio tenga la posesión. Es evidente que estas dos cosas son diferenciables: una cosa es tener físicamente la cosa como dueño, otra es tener derecho de propiedad sobre la cosa. Para reflejar este hecho podemos modificar la figura I y agregarle una nueva línea, paralela y adyacente a la primera:

Figura II

El derecho de propiedad y la posesión en el caso normal (posesión del dueño)

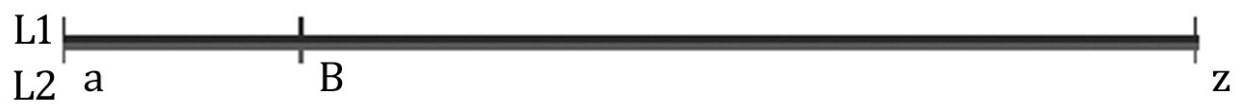

En la figura II la línea 1 (L1) es una línea normativa, que representa la existencia y vicisitudes de la propiedad como derecho subjetivo, mientras la línea 2 (L2) es una línea fáctica, que representa la detentación material de la cosa, la posibilidad real (no el derecho) de usar, gozar y disponer de la cosa.

71 Peñallillo (2006), p. 71. 
Que las dos líneas coincidan no es, por cierto, casualidad. La razón por la que importa el derecho de dominio es precisamente porque el dueño puede gozar y disponer arbitrariamente de la cosa, y para eso necesita tenerla bajo su control. Por regla general, las condiciones de operación de los modos de adquirir (originarios y derivativos) vinculan la atribución de la propiedad al control físico sobre la cosa, asegurando (=haciendo probable) de ese modo que las dos líneas seguirán siendo adyacentes y paralelas. El adquirente se hace dueño sólo cuando el tradente le entrega la cosa, el dueño de la cosa principal se hace dueño cuando la cosa accesoria se une a ella, etc. En la figura II hay un evento de adquisición originaria (por ejemplo, por ocupación) que queda registrado como (a); un evento de transferencia del dominio (por ejemplo, una compraventa de la cosa seguida de tradición) que queda registrado como (b) y un evento de extinción del dominio (por ejemplo, por destrucción de la cosa), que queda registrado como (z). Nótese que tanto (a) como (b) y (z) son eventos de los que aparece registro en ambas líneas, la normativa y la fáctica, porque la adquisición, transferencia o extinción del dominio son también eventos de adquisición o pérdida de la posesión.

Ahora bien, que por regla general hacerse con el dominio implique hacerse con el control de la cosa no significa que ambas líneas corran siempre juntas.

Podemos imaginarnos un caso como el descrito en el artículo 730: A es mero tenedor de una cosa de propiedad de C y la usurpa. Dándose por dueño de ella, la enajena a B, haciendo tradición real (supongamos, para evitar complicaciones que nos desvíen del argumento, que se trata de una cosa mueble). La enajenación de la cosa hecha por A a B no afecta para nada el dominio de C, lo que se representa aquí porque de esa usurpación y pretendida enajenación de $\mathrm{A}$ a $\mathrm{B}$ (que en la figura III está representada como (c)) no queda registro alguno en L1, la línea que representa el derecho de dominio, aunque altera L2, la línea que marca la detentación de la cosa como dueño. Un evento de este tipo, apto para terminar con una posesión y para hacer surgir una distinta pero no para transferir el dominio, será denominado una "anomalía". En efecto, cuando el usurpador hace tradición de la cosa a un tercero, este adquiere la posesión (art. 730):

Figura III

Enajenación a un tercero por quien no es dueño de la cosa.

La noción de "anomalía"

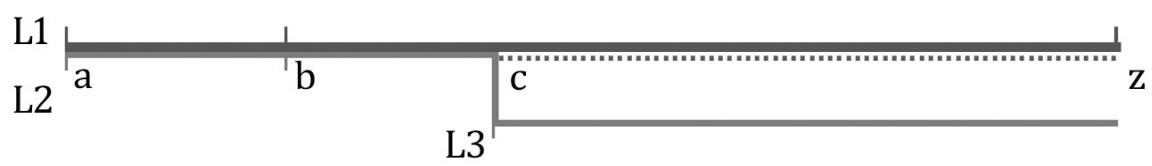


Observación: Las situaciones jurídicas que se prolongan en el tiempo son representadas aquí como líneas horizontales, para evitar que se vuelvan sobre sí mismas. Cada línea posesoria (pero no L1, la línea dominical) termina con una anomalía: L2 termina en (c). La anomalía (c) es al mismo tiempo el punto de extinción de una línea posesoria (L2) y el punto de origen de la línea siguiente (L3). La línea vertical que une el fin de L2 y el inicio de L3 es más problemática: representa alguna forma de unión entre las líneas, cuando entre ellas no hay continuidad. Podría, entonces, no aparecer: después de todo, esa es la idea contenida en el art. 717, cada posesión principia con ella misma. Pero eso sería llevar las cosas demasiado lejos. Y en todo caso, la unión de L2 y L3 por la vertical en (c) a pesar de que (c) es una anomalía representa la idea de que hay algo que es común a todas las líneas, que hace que todas esas líneas sean sobre lo mismo: la cosa misma (sobre la relevancia de la unidad de todas las líneas posesorias respecto de una misma cosa, véase infra, n. 76). La figura III representa la situación en la que la posesión (entendida a la manera del art. 700) se ha separado del dominio, lo que ocurre en (c). (c) es un hecho que termina una línea posesoria e inaugura una nueva, sin que ello tenga correlato en L1, la línea dominical. Eso será llamado una "anomalía". La noción de anomalía nos permite una definición de línea posesoria (lo que el art. 717 llama un "serie sucesiva" de posesiones): es una sucesión de posesiones entre dos anomalías.

Es importante notar que, como ya hemos observado, la anomalía no afecta en absoluto al dominio, y por eso nada cambia en L1: habrá que decir que B simplemente no es dueño y que $C$ sigue siendo dueño en exactamente el mismo sentido en el que lo era antes de la separación de las dos líneas. Pero algo ha ocurrido: ahora hay una persona que detenta la cosa como dueño aunque no tiene derecho sobre la cosa, y el dueño ya no la detenta aunque tiene derecho a detentarla. El dueño es protegido en tanto titular del derecho de dominio, el poseedor es protegido en tanto poseedor.

La razón por la que la anomalía no afecta a L1 es que esta es normativa, no fáctica, y las posiciones normativas son (o al menos pretenden ser) inmunes a las anomalías (las expectativas normativas no aprenden, sino insisten). L2 sí es afectada, porque ella es una línea que representa la detentación material de la cosa (da cuenta de un hecho, no de un derecho): el hecho de que el mero tenedor haya usurpado y enajenado la cosa a un tercero no priva al dueño de su dominio, pero sí de la cosa misma.

Ahora bien, lo interesante es que el hecho de que L2 sea puramente fáctica no implica que el derecho no pueda tratarla como si fuera normativa. Es importante distinguir el caso de una línea fáctica tratada como si fuera normativa de la normativización de la línea fáctica, que deja entonces de ser fáctica.

Esto puede parecer un intento de rizar el rizo. Pero para aclarar las cuestiones debemos atender a una posibilidad más, representada ahora en la figura IV: 
Figura IV

Líneas posesorias sucesivas

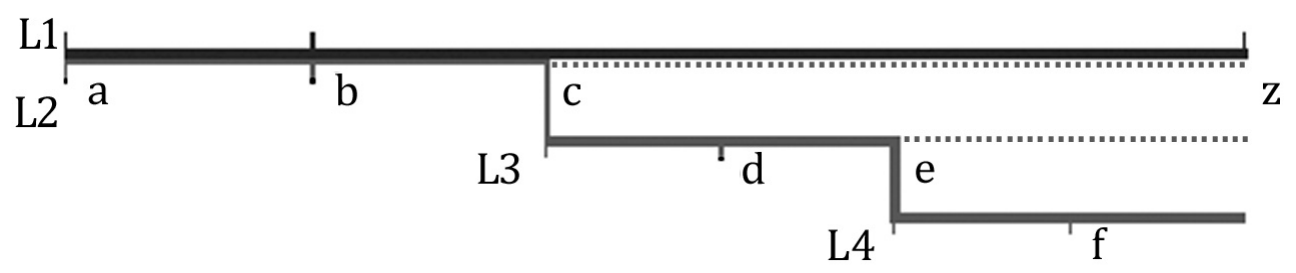

En la figura IV, la anomalía que Ilevó en (c) a la extinción de L2 y al nacimiento de L3 (ambas líneas puramente fácticas) se ha repetido en (e) y L3 se extingue para que nazca L4. La relación de L4 con L3 parece ser la misma que la existente entre esta y L2. Y en alguna medida lo es, pero hay entre ambas una diferencia. L2 es la que corresponde directamente a L1, que es normativa. Es indudable que la prolongación de L1 después de (c), la anomalía que pone término a L2, se explica trivialmente porque las posiciones normativas no son necesariamente afectadas por irrupciones fácticas. Esta explicación ya no nos sirve para explicar la continuidad (marcada por eso en línea punteada) de L2 después de (c), una anomalía que pareciera ponerle término. La pregunta es: si L2 es puramente fáctica, ¿cómo es que continúa después de la anomalía que le pone término? En el caso preciso de L2 podríamos decir que, como es paralela a L1, de algún modo la normatividad de L1 se le contagia (yo creo que esto no tiene sentido, pero no importa ahora, porque aun si lo aceptamos, eso solo posterga el problema, no lo soluciona). Pero en la figura IV, ¿qué ocurre con L3 después de (e), la anomalía que le pone término? Pareciera que en L3 no hay ninguna normatividad: ciertamente no recibe normatividad de L1, que es la única normativa. Entonces es pura facticidad. Pero si es pura facticidad, ¿qué queda de ella una vez que es fácticamente extinguida en (e)? La conclusión parece inevitable: L3 se extingue en (e), el punto de origen de L4. Y esto no es extraño: "sea que se suceda a título universal o singular, la posesión del sucesor principia con él", conforme a lo dispuesto por el artículo 717. Esto quiere decir: la línea posesoria en realidad no es una línea, es una sucesión de hechos. De cada posesión todo lo que puede decirse es que empieza cuando empieza y termina cuando termina. De hecho, la idea misma de una línea en que se representan varias posesiones sucesivas parece impropia, porque vincula las posesiones que el artículo 717 declara independientes entre sí.

Esta idea ya se nos ha aparecido cuando preguntábamos, siguiendo la explicación invertida tradicional, qué es lo que protege la acción publiciana, 
y aparece también al preguntarse, conforme a la misma explicación invertida, qué protege la querella de restitución (art. 926), que corresponde a "el que injustamente ha sido privado de la posesión"72. Si la posesión es un hecho, ¿qué es lo que tiene el que ya ha perdido la posesión? Esto es importante, y tendrá que ser discutido en su momento. Lo que ahora importa es que el mismo problema no se reproduce en el caso de L1, que no es una línea fáctica. Por eso no hay problema para explicar qué es lo que invoca el reivindicante cuando ejerce la acción reivindicatoria contra el poseedor. Pero sí parece problemático explicar qué es lo que invoca el poseedor que invoca su acción publiciana o su querella de restitución. Como está dicho más arriba, al hablar de "líneas posesorias" pareciera que estamos tratando a la posesión como si fuera normatividad.

Y esta es la clave: las posesiones son independientes entre sí, pero la ley las trata como si fueran posiciones normativas para ciertos efectos. Esto es tratar una línea fáctica como si fuera normativa. Si como se trata de puras posiciones fácticas que no tienen relaciones entre sí aceptáramos que no pueden distinguirse líneas posesorias, entonces tendríamos que concluir que la pretensión del que adquirió la posesión en (e) es indistinguible, tan fáctica como la del que adquirió la posesión en (f). Pero el derecho distingue (e) de (f), y con buenas razones: (e) es una anomalía y no pretende siquiera no serlo; pero (f) no es una anomalía, porque mirando solo al hecho o acto que da origen a la posesión (es decir, solo a (f) mismo) y haciendo caso omiso de lo demás, la pretensión del adquirente en ( $\mathrm{f}$ ) es regular como no lo es la del adquirente en (e). Esto quiere decir: la posesión que se inicia con (f) está conectada a la posesión anterior a (f) porque ambas contienen la misma pretensión de dominio, porque entre ambas hay lo que a continuación llamaremos una relación preservativa del dominio. Esto es lo que permite representar a L4 como una línea y a (f) como un evento normal dentro de ella. Podemos decir: (f) es una normalidad (por consiguiente, parte de una línea posesoria), (e) una anomalía (que pone fin a una línea posesoria e inaugura una nueva).

En conclusión: una línea posesoria comienza con una anomalía y termina con la siguiente. Cada línea posesoria representa una pretensión de dominio, y para entender cómo opera en tanto pretensión de dominio hay que considerarla como si fuera una línea normativa (aunque no lo es): en (f) no

72 Que es discutida en AtriA (En prensa): "El sistema de acciones reales, parte especial. La dimensión dinámica del dominio". 
se transfiere el dominio, por cierto (no hay dominio en L4), y no se transfiere la posesión (porque la posesión nunca se transfiere, porque es un hecho). Lo que se transfiere es la pretensión de dominio.

Incidentalmente, esta explicación da cuenta (aunque esto no será desarrollado más que la explicación que sigue) de la idea de agregación de posesiones. Para que una posesión sea agregable a otra, es necesario que no haya interrupción entre ellas, que ambas formen lo que el inciso $2^{\circ}$ del artículo 717 Ilama una "serie no interrumpida". ¿Qué es apto para interrumpir y cuándo hay o no hay interrupción? Como podrá observarse, esto es lo mismo que preguntarse qué es lo que diferencia a (e), una anomalía, de (f), una normalidad. Llamemos a dos posesiones que forman una "serie no interrumpida" posesiones "contiguas". Entonces

Contigüidad (Def.=) Dos posesiones son contiguas cuando entre ellas hay una relación preservativa del dominio.

Todo acto por el que termina una posesión y se inicia una nueva es una normalidad o una anomalía. Cuando dos posesiones sucesivas forman una serie no interrumpida, es decir, cuando están unidas por una relación preservativa del dominio, es decir, cuando son contiguas, el hecho o acto que pone fin a una de ellas y comienza la siguiente es una normalidad. Así, (b), (d) y (f) en la figura IV.

La noción central aquí es la de una relación preservativa del dominio, que puede ser definida de la siguiente forma:

Relación preservativa del dominio (Def.=) Dos posesiones están unidas por una relación preservativa del dominio si la relación entre ambas es tal que del hecho de ser el poseedor anterior dueño se sigue que el posterior es dueño.

Corolarios. De dos posesiones contiguas puede decirse que:

(i) se encuentran en la misma línea, entre dos anomalías sucesivas;

(ii) contienen la misma pretensión de dominio;

(iii) pueden agregarse.

Una relación preservativa del dominio no supone dominio, porque dos posesiones pueden estar unidas por una relación preservativa del dominio incluso cuando en la línea respectiva no haya dominio alguno que preservar, como ocurre en L3 y en L4: la posesión que se inicia en (d) y la que termina ahí están unidas por un vínculo preservativo del dominio, y por eso constituyen una línea definida por la misma pretensión de dominio: el poseedor después de $(\mathrm{d})$ reclama ser dueño porque el poseedor antes de (d) reclamaba ser dueño (lo mismo vale de ( $\mathrm{f}$ ) en L4). Todo esto puede ser dicho a sabiendas 
de que en L3 (y en L4) no hay dominio. "Relación preservativa del dominio" es el antónimo de "anomalía".

La idea de línea posesoria, que une ordenadamente a todas las posesiones vinculadas entre sí por relaciones preservativas del dominio, y que comienza con una anomalía y termina con la siguiente, permite explicar la noción de "mejor derecho". Obsérvese lo ocurrido en (d). Sin que debamos tener una opinión sobre si hay o no dominio en L4, podemos decir que la pretensión de ser dueño que definía a esa línea no se extinguió, sino se transfirió al adquirente en (d), quien reclama ser dueño porque su tradente reclamaba ser dueño. El tradente en (d) ya no pretende ser dueño y si hubiera sido dueño ya no sería dueño (si antes de (d) hubiera sido dueño de la cosa habría transferido el dominio al poseedor siguiente, que sería el dueño). Por consiguiente, el adquirente en (d) tiene, evidentemente, mejor derecho que el tradente en (d).

Pero (e), la anomalía que termina L3, no tiene el mismo efecto, precisamente porque es una anomalía (un hurto, por ejemplo). El ladrón que adquirió la posesión en (e) no tiene una pretensión de dominio que se funde en la pretensión de la víctima del hurto. Su pretensión de dominio (del ladrón) es independiente y originaria. Como niega ilícitamente la pretensión de dominio anterior, el que adquiere la posesión en (e) tiene peor derecho que el que pierde la posesión en virtud de (e).

Ahora podemos ofrecer una explicación de la idea de que una posesión sea "mejor" que otra en el sentido del artículo 894:

Mejor derecho (Def.=) Una posesión que no se extinguió de una manera apta para transferir el dominio; es decir, una posesión que se termina en virtud de la anomalía que pone fin a la línea posesoria a la que pertenece, es mejor que cualquier posesión que pertenezca a la línea que se inicia con esa anomalía o a líneas posesorias posteriores.

Se sigue de lo anterior que A puede tener mejor derecho que B incluso si es el caso que ni A ni B tienen derecho. Se sigue también de lo anterior una explicación de qué es lo que puede reclamar el poseedor regular que ha perdido la posesión pero no es dueño. Se trata, como es evidente, de un poseedor cuya posesión estaba en una línea como L3: una línea que se inició por una anomalía, por lo que nunca hubo dominio en ella y terminó ya por otra anomalía. Lo que queda es la proyección de la línea, constituida por la pretensión de dominio, que basta para declararla mejor que la pretensión que da contenido a la línea posesoria siguiente. Como se trata de una prueba relativa del dominio, lo que debe probarse no es que en alguna de las líneas hay dominio, sino que si hubiera dominio, estaría en una posesión y no en la otra. 
Todo lo anterior debe ser entendido como una explicación civil de lo que quiere decir "mejor derecho". Como tal, debe ser ajustada por consideraciones procesales, que tienen que ver con lo que se puede discutir en un juicio entre A y B. Una anomalía puede ser un acto jurídico nulo o un hecho ilícito. Si se trata de un hecho ilícito (pensemos, por ejemplo, que en la figura IV (e) es el hurto de la cosa) eso podrá ser discutido en cada juicio en que sea relevante, pero ¿qué tal si es un contrato obtenido con dolo? Piénsese en tres poseedores sucesivos, A, B y C. B compró válidamente la cosa a A, que se la entregó; $\mathrm{C}$ obtuvo con dolo el contrato de compraventa y logró que B le entregara la cosa.

Lo primero que hay que decir es que $B$ tiene mejor derecho que A, porque la pretensión de dominio de A se extinguió regularmente cuando vendió y enajenó la cosa a B (es decir, la posesión de B y la de A están unidas por una relación preservativa del dominio). $B$, por su parte, está respecto de $C$ en la misma posición que $\mathrm{A}$ a su respecto mientras el contrato no es declarado nulo, porque mientras el contrato es válido el paso de B a C será una normalidad. La declaración de nulidad del contrato hace que ese paso deje de ser una normalidad y pase a ser una anomalía, por lo que ahora B tiene mejor derecho que $\mathrm{C}$. Al reivindicar, $\mathrm{B}$ no necesitará producir prueba absoluta de su dominio, porque con el mérito de la declaración de nulidad podrá probar que tiene mejor derecho que $C$. En efecto, una vez que el contrato es declarado nulo el mejor derecho de $\mathrm{B}$ sobre $\mathrm{C}$ es evidente, porque ahora $\mathrm{B}$ es la posesión final de la línea, el paso de $\mathrm{B}$ a $\mathrm{C}$ una anomalía, y C es la posesión inicial de la línea siguiente ${ }^{73}$.

El caso más obvio de mejor derecho es, entonces, el de dos posesiones separadas solo por una anomalía: la última de la línea anterior es "mejor" que la primera de la línea posterior.

¿Es posible decir algo más? Si D roba la cosa a C, ¿puede alegar B que tiene mejor derecho que D?

\footnotetext{
${ }^{73}$ Solo una referencia aquí a la diferencia entre la nulidad absoluta y la nulidad relativa. Un acto o contrato relativamente nulo da a aquel en cuyo beneficio lo ha establecido la ley un derecho a hacer subsistir el contrato, por lo que será él quien podrá decidir si se ha de pedir o no la nulidad: si el que tiene la acción no la ejerce, no hay nulidad posible de ser declarada (art. 1894). Pero nadie tiene derecho a mantener la validez de un contrato absolutamente nulo, y por eso nadie está en posición de bloquear el ejercicio de la acción de nulidad, que la tiene todo el que necesite tenerla por una razón mínimamente válida (art. 1683). Así, aquel cuya posibilidad de reivindicar la cosa depende de la nulidad de un contrato anterior del que no es parte podrá pedir esa nulidad si se trataba de una nulidad absoluta, pero no si era una nulidad relativa, porque en ese caso hay alguien (que no es él) que tiene derecho a decidir si ese contrato subsiste o no.
} 
Para alegar mejor derecho que D, B deberá mostrar que su pretensión de dominio no se extinguió, es decir, que la suya fue la última posesión de una línea (es decir, que su pérdida de la posesión fue una anomalía). Pero su posesión terminó por una enajenación. Ahora bien, esa enajenación, desde el momento en que el contrato es declarado nulo, cuenta como una anomalía. Pero mientras no sea declarado nulo no es una anomalía. Hasta entonces B estará en la misma línea que C, y la línea terminará en C, con la anomalía consistente en el hurto de D a C. B no puede alegar mejor derecho contra D, sin obtener la nulidad del contrato con B. Una vez obtenida, podrá demandar la reivindicación de la cosa de manos de quien esté, y no tendrá que probar más que mejor derecho si se dirige en contra de cualquiera que esté en una línea inferior a la suya.

Nótese que esto implica que la acción reivindicatoria que sigue a una declaración de nulidad normalmente será publiciana. Esto tiene que ver con las condiciones procesales para la declaración de nulidad, más que con la lógica civil del argumento. Si los eventos intermedios fueran hechos ilícitos, no actos jurídicos viciados de nulidad, entonces sí sería posible la prueba de mejor derecho per saltum: si A es poseedor y B roba la cosa y luego $C$ le roba la cosa a B, A puede reivindicar la cosa contra $C$ sin necesidad de producir prueba absoluta de su dominio, sino solo mostrando que su posesión terminó por el robo de $\mathrm{B}$ y la de $\mathrm{C}$ al robo que este hizo a $\mathrm{B}$, por lo que es mejor que la de $\mathrm{C}$.

¿Hasta dónde llega la prueba de mejor derecho? Es interesante notar que, en principio, una acción que descanse en la prueba relativa del dominio reemplaza perfectamente a una que descansa en la prueba absoluta. La relatividad de la prueba de mejor derecho implica que A puede tener mejor derecho que $B$ incluso si $A$ no tiene derecho, pero en ningún caso lo contrario: no es posible que $B$ tenga derecho sobre la cosa y A no lo tenga y que a pesar de eso A tenga mejor derecho que B. Es decir, todos los casos que podrían ser solucionados con la acción reivindicatoria pueden también ser solucionados con la acción publiciana, y la acción publiciana soluciona más casos y de modo más fácil porque descansa en prueba relativa y no en prueba absoluta. ¿Qué sentido tiene la prueba absoluta cuando es posible la prueba relativa?

La respuesta es: ninguno, siempre que uno tenga claro qué quiere decir que "sea posible" la prueba relativa. En rigor, siempre es posible, en el sentido de que las líneas posesorias siempre existieron, por lo que siempre cada uno ocupa algún lugar en alguna línea posesoria (la unidad, recuérdese, está dada por la cosa). Pero probar relativamente tiene su dificultad, y es importante observar qué es lo que fija el grado de dificultad. 
La prueba relativa supone la reconstrucción de las líneas posesorias. No toda la historia de la propiedad sobre la cosa respectiva, por cierto, sino solo las líneas que unen a demandante y demandado: si B hurtó la cosa de A, la línea a reconstruir es breve y comprende solo la anomalía que termina la línea de $\mathrm{A}$ y comienza la de $\mathrm{B}^{74}$. Si $\mathrm{A}$ está demandando no a $\mathrm{B}$, quien le hurtó la cosa, sino a $C$, quien adquirió la cosa de $B$, tendrá que probar el hurto de $B$ (la anomalía que puso fin a su línea e inauguró la siguiente), y también que la posesión de $\mathrm{C}$ está unida a la de $\mathrm{B}$ mediante una relación preservativa del dominio. Si $\mathrm{C}$ enajenó la cosa a $\mathrm{D}$, A tendrá que probar la anomalía de $\mathrm{B}$, la transferencia de B a C y la transferencia de C a D. Si E hurtó la cosa a D, tendrá que probar dos anomalías, y las líneas entre ellas, etc.

Lo que lo anterior muestra es que hay un momento en que la reconstrucción de las líneas posesorias intermedias se puede hacer demasiado difícil o imposible, o al menos más difícil que probar absolutamente el dominio. Por eso es que la posibilidad de la prueba relativa no hace redundante la prueba absoluta: ella debe existir como posibilidad cuando las vicisitudes intermedias de la posesión de la cosa no puedan ser reconstruidas. La reivindicatoria opera entonces per saltum y supone ignorar las posiciones relativas de demandante y demandado y probar derechamente que el demandante es dueño, por lo que no importa cuál es la posición relativa de cada uno.

No es, entonces, que la ley fije condiciones de improcedencia de la prueba relativa, que hagan necesaria la prueba absoluta como compensación; es que la propia lógica de la prueba relativa tiene sus cargas, y la situación de las partes puede significar que ellas son más gravosas que la posibilidad alternativa de prueba absoluta. El principio fundamental del sistema de acciones reales del Código Civil es no exigir al que necesita una acción más de lo que es necesario para determinar si la protección que busca está justificada ${ }^{75}$.

\section{La acción del art. 915}

La interpretación del artículo 915: consideraciones generales. Conforme al artículo 915,

"Las reglas de este título se aplicarán contra el que poseyendo a nombre ajeno retenga indebidamente una cosa raíz o mueble, aunque lo haga sin ánimo de dueño".

\footnotetext{
${ }^{74}$ Nótese que por esto es importante que en la representación gráfica de las líneas posesorias las anomalías no obstan a que las líneas posesorias (horizontales) sean unidas por líneas verticales, de modo que hay una línea (no recta) que une a todas las posesiones, dada, como fue explicado en la Observación a la figura III, por la cosa misma.

75 ATRIA (En prensa): "El sistema de acciones reales, parte general".
} 
Este artículo ha dado origen a variadas controversias. Antes de explicar la interpretación de él que a mi juicio es correcta en el contexto del sistema de acciones del Código Civil, puede ser útil enumerar las alternativas que han tenido relevancia dogmática o jurisprudencial.

1. Es una acción contra el mero tenedor que, requerido, no restituye la cosa. Esta es la explicación que dan los primeros comentaristas del Código Civil, como Robustiano Vera y Jacinto Chacón ${ }^{76}$. Vera, por ejemplo, explicaba que

"el artículo 915 contempla el caso en que puede establecerse la acción reivindicatoria contra el nuevo tenedor, lo que por cierto es una excepción a la regla de que la acción reivindicatoria se da solo contra el que nos ha quitado la cosa que poseíamos. Así, por ejemplo, si el nuevo tenedor de la cosa, el que la tiene con el carácter de prendario, de secuestre, de usufructuario, de usuario, de habitador o de arrendatario, se alzare con la cosa se entabla entonces acción reivindicatoria contra él para obligarlo a restituirla"77.

La afirmación transcrita de Vera es ambigua respecto de un punto crucial: ipermite la regla del artículo 915 dirigirse en contra de cualquier mero tenedor? Al decir que el mero tenedor contra el que la acción procede es el que "se alzare con la cosa", Vera parece estar indicando que ha de tratarse de un mero tenedor que en algún momento no estuvo alzado, es decir, que se trata de alguien que estuvo vinculado al que se reclama dueño y ahora es demandante por un título que reconocía el dominio de este y en un momento posterior se alzó con la cosa, es decir, se negó a restituir. Alternativamente, uno podría entender a Vera en el sentido de que, dado lo que "mera tenencia" significa (art. 714), todo mero tenedor que no restituye la cosa a requerimiento del dueño se ha alzado con la cosa. La acción del artículo 915 sería una acción que tiene todo el que reclame ser dueño de la cosa en contra de cualquiera que la tenga a título de mera tenencia ${ }^{78}$. Para distinguirla, esta será enumerada más abajo, como una tercera posible interpretación del artículo 915 (debemos distinguir la cuestión de si Vera defendía esta tesis de la cuestión de identificar correctamente esta tesis). Para imputarle esta tesis a Vera es necesario afirmar que todo mero tenedor que no restituye a quien reclama ser dueño se ha "alzado con la cosa", lo que es a mi juicio un error.

76 Chacón (1881), p. 546; Vera (1894), p. 374.

77 VERA (1894), p. 374.

${ }^{78}$ Como lo hace Barrientos (2005), pp. 221-249, que describe la tesis que luego imputa, entre otros, a Vera defiende diciendo que el artículo 915 "permitiría entablar [la acción reivindicatoria] en contra del 'mero tenedor'" (232). 
En efecto, el arrendatario del poseedor que se rehúsa a entregar la cosa al que se reclama dueño en contra de su arrendador no se ha "alzado": él, a mi juicio, está jurídicamente autorizado para hacer, en sede judicial o no, lo que dispone el artículo 896: sostener que no le corresponde decidir si la pretensión de este tercero es correcta, y que se dirija contra el poseedor, su arrendador. El mero tenedor "alzado" sería el que reconocía el dominio del demandante y se niega a restituir. Pero entonces la acción del artículo 915 no procedería en contra de cualquier mero tenedor, sino solo del mero tenedor que reconocía el dominio del propio demandante ${ }^{79}$.

2. El artículo 915 no contiene acción alguna, porque solo se refiere a las reglas sobre prestaciones mutuas. Esta tesis se le imputa a Luis Claro Solar ${ }^{80}$ y ha sido defendida por Fernando Rozas ${ }^{81}$, entre otros.

3. La acción del artículo 915 permite generalmente la reivindicación contra el mero tenedor. Esta es una posición que es más fácil encontrar en decisiones judiciales que en textos académicos. De hecho, M. F. Pérez, descansando en un bastante exhaustivo análisis jurisprudencial, la califica como "la interpretación que mayoritariamente sigue la jurisprudencia hoy en día" 82. A. Selman, por su parte, cree que esta interpretación es "la más utilizada por nuestra jurisprudencia en la actualidad". En ambos casos las referencias citadas son solo sentencias judiciales ${ }^{83}$. Se trata, en lo que se distingue de

${ }^{79}$ Esta es una ambigüedad constante. Así, Kiverstein titula el apartado en el cual discute la acción del art. 915 de este modo: "La acción reivindicatoria se puede dirigir en contra del mero tenedor", pero con eso no quiere decir que la acción proceda contra cualquier mero tenedor, sino contra quien tenía la cosa como mero tenedor del demandante: "El arrendador o el comodante tienen dos acciones para obtener la restitución de la cosa arrendada o dada en comodato: a) La acción personal que nace del respectivo contrato. b) La acción reivindicatoria". KiverSTEIN H. (2006), p. 221.

${ }^{80}$ La tesis de Claro Solar, sin embargo, es la misma que se sostendrá en este artículo y que corresponde a la primera identificada: el art. 915, según Claro Solar, es aplicable al caso "de un individuo que sin ser poseedor, porque retiene la cosa sin ánimo de señor o dueño, se resiste indebidamente, es decir, sin derecho alguno a seguir con la cosa, a restituirla a la persona a cuyo nombre la poseía". (CLARO SOLAR (2013), p. 417, §1804).

81 ROZAS (1998), p. 375.

82 Perez (2014), p. 391.

${ }^{83}$ Selman (2011), p. 60. Pérez (2014, pp. 390-393) cita solo sentencias judiciales y una memoria de prueba de 2001. Además de la jurisprudencia discutida en las pp. 60-62, Selman solo cita a Alessandri, que habría adscrito, según él, a esta interpretación en la versión taquigráfica de sus clases tomadas por Onías León y publicadas en 1937, aunque la habría abandonado después (62 n. 10). Pero no es claro que Alessandri ahí defienda esa interpretación. Alessandri hace referencia al caso en que "un mero tenedor de la cosa o un simple detentador se quede con ella o se niegue a restituirla". En ese caso, sostiene Alessandri, "el propietario puede pues optar entre la acción personal proveniente del contrato en cuya virtud el tenedor detenta la cosa, y la acción reivindicatoria". (AlessandrI (1937), 
la primera interpretación, de casos en los que un poseedor inscrito pretende reivindicar la cosa de manos del que detenta materialmente la cosa.

Es interesante observar que la primera interpretación fue la que resultaba natural a los primeros comentaristas del Código Civil, que escribían antes del desarrollo de la "teoría" de la posesión inscrita. Esto es interesante porque es la posesión inscrita la que crea el problema que se ha pretendido solucionar mediante la extensión de la acción del artículo 915.

En efecto, el surgimiento de la posesión inscrita y el consiguiente vacío creado por el hecho de que el poseedor inscrito que ha perdido la detentación de la cosa no reúne las condiciones para ejercer la acción reivindicatoria contra el que posee materialmente el inmueble respectivo llevaron a interpretar el artículo 915 en el sentido de que contenía precisamente la acción que faltaba ${ }^{84}$. Esto es quizás así, pero no debemos llegar a esa conclusión demasiado rápidamente. Es importante distinguir, al menos inicialmente, el sentido original de este artículo (qué es lo que significa en el contexto del sistema de acciones del Código Civil, dadas las características que este tiene, lo que incluye el déficit que hemos encontrado) de qué servicios puede prestar, ya que necesitamos encontrar una acción para el dueño en el caso señalado. Ahora nos interesa solo lo primero.

Oscuridad de la referencia. Lo primero que debe señalarse respecto del artículo 915 es la notoriamente oscura especificación de su referencia. ¿Qué es lo que se aplicará también al caso del que retiene indebidamente? "Las reglas de este título" incluyen al artículo 898, que define la acción reivindicatoria: ¿quiere decir que contra el que retiene indebidamente hay acción reivindicatoria? Pero esas mismas reglas incluyen al artículo 895, que señala que la acción reivindicatoria se dirige contra el poseedor: ¿quiere decir que como el que retiene indebidamente no es poseedor no puede ser destinatario de la acción reivindicatoria? Y también incluyen las reglas de prestaciones mutuas: ¿quiere decir que esas reglas, con independencia de las acciones, se aplican para determinar las compensaciones recíprocas que se deben las partes?

Criterios generales de guía. Nada de esto es obvio. Como guía para la interpretación, hay dos consideraciones generales que es posible formular

p. 211). Es decir, el caso que Alessandri tiene en mente es el caso en que el mero tenedor era mero tenedor del propio demandante.

${ }^{84}$ Véanse Domínguez Águila (2005), p. 348; Pérez (2014); Barcia (2014), pp. 367-390, y especialmente Selman (2011), que acertadamente observa, acerca de la jurisprudencia que permite la acción del art. 915 respecto de cualquier mero tenedor, que "su principal fundamento pareciera no ser jurídico, sino más bien nace de la urgencia de resolver problemáticas que no encuentran una solución admisible frente a determinadas situaciones de hecho que resultan injustas" (ibid, p. 60). 
en abstracto. La primera es que el artículo 915 tiene que hacer una diferencia. Es decir, una interpretación en que la existencia del artículo 915 tenga consecuencias jurídicas es en principio preferible a otra en que reitera una regla general. Nótese que esto es solo un argumento a favor de una interpretación, no una consideración decisiva para desecharla o aceptarla. Hay reglas redundantes en el Código Civil (véase por ejemplo el art. 1873), y el Mensaje explica por qué esas reglas son mucho más frecuentes de lo que podrían haber sido:

"Por lo que toca al mérito y plan que en este código se han seguido, observaré que hubiera podido hacerse menos voluminoso, omitiendo ya los ejemplos que suelen acompañar a las reglas abstractas, ya los corolarios que se derivan de ellas, y que para la razón ejercitada de los magistrados y jurisconsultos eran ciertamente innecesarios. Pero, a mi juicio, se ha preferido fundamentalmente la práctica contraria, imitando al sabio legislador de las partidas. Los ejemplos ponen a la vista el verdadero sentido y espíritu de una ley en sus aplicaciones; los corolarios demuestran lo que está encerrado en ella, y que a ojos menos perspicaces pudiera escaparse. La brevedad ha parecido en esta materia, una consideración secundaria".

La segunda consideración es que la regla del artículo 915 tiene que ser consistente con las reglas del título al que pertenece. Esto no quiere decir que no pueda contener una excepción o una regla contraria a algunas de las que aparecen en el resto del título. Lo que quiere decir es que si es una excepción, ella debe estar caracterizada de alguna manera, contenida para que no se aplique a todos los casos. En efecto, sería absurdo que el título XII hubiera dispuesto que la acción reivindicatoria debe dirigirse contra el poseedor (art. 895), por lo que si el mero tenedor es demandado tiene el deber de declarar a nombre de quién posee (art. 896) y que si alguien se hace pasar por poseedor es responsable de los perjuicios (art. 897) y que si alguien deja de poseer en ciertos casos puede ser destinatario de una acción distinta de la reivindicatoria, una acción personal (arts. 898, 900), y que después de toda esta regulación, el título XII terminara disponiendo que la acción reivindicatoria procede también contra el mero tenedor. Es decir, el artículo 915 puede contener una excepción, pero debe ser una excepción que no reduzca a la irrelevancia el contenido de la regla general, y para eso necesita ser una excepción contenida de alguna manera, debe ser posible identificar los casos excepcionales, encontrar para ellos una racionalidad especial que justifica la excepción y una diferenciación entre ellos y todos los demás casos "normales" donde se aplica la regla general. En caso contrario no será una excepción, sino una antinomia. 
¿Cuáles son "las reglas de este título"? La primera cuestión es, entonces, a qué se refiere: ¿contiene una especie de acción reivindicatoria contra el que retiene indebidamente (habrá que ver después quién es ese)? Ya hemos visto que algunos han sostenido que no se trata de crear una acción, porque no se dirige en contra del poseedor. Como no hay posesión, sigue el argumento, la referencia a "las reglas de este título" no puede ser a la acción reivindicatoria, que exige ser dirigida contra el poseedor (art. 895). La referencia tiene que ser a las otras reglas de este título, las que no especifican las condiciones de procedencia de la acción reivindicatoria. Se trata de las del párrafo 4, sobre prestaciones mutuas. No hay tal cosa como una "acción del artículo 915", porque lo que el artículo 915 dispone es que si el que retiene indebidamente restituye, tiene las obligaciones y derechos que tiene el poseedor que es obligado a restituir la cosa ${ }^{85}$.

Esta interpretación respeta la segunda de las dos condiciones generales identificadas más arriba, pero no la primera. No era necesario el artículo 915 para hacer aplicable las reglas de las prestaciones mutuas al que retiene indebidamente, y no hay razón alguna por la que ese caso deba recibir una atención especial del legislador desde el punto de vista de las prestaciones mutuas. En efecto, la doctrina ha concluido sin mayor problema que las reglas de las prestaciones mutuas son de aplicación general ${ }^{86}$ y, por lo tanto, aplicables a casos que en rigor no son los del poseedor vencido. Al notar estos casos, la pregunta que esta interpretación no puede responder es: ¿qué hay de especial en el caso del que retiene indebidamente, que se justifica que el legislador haga explícito en su caso que tiene derecho a las prestaciones mutuas, pero no en los demás casos?

De este modo esta interpretación parece ser guiada solamente por la necesidad de encontrar algún significado al artículo 915 sin conceder lo que él bastante claramente implica: que hay acción contra el que retiene indebidamente.

¿Quién es el que "retiene indebidamente"? La postura hoy dominante es que hay tal cosa como la "acción del artículo 915". Es decir, que ese artículo sí extiende el ámbito de aplicación de la acción reivindicatoria, permitiendo la reivindicación en casos en los cuales las reglas generales no la permitirían. Con esto las interpretaciones hoy aceptadas satisfacen la primera condición general indicada más arriba. Entre ellas, será la segunda condición la que permita elegir.

85 Veloso Chávez (1947), pp. 34-35; adicionalmente supra, nn. 82-83.

${ }^{86}$ Alessandri Somarriva et al. (1998), p. 293; Peñallillo (2006), p. 239. 
La cuestión central es quién es el "injusto retenedor" contra el cual el artículo 915 da una acción. Y aquí, en general, dos respuestas son posibles: la primera es que es cualquier mero tenedor. Otros han sostenido que se trata de una "acción puramente restitutoria contra el mero tenedor" ${ }^{87}$.

Desde un punto de vista puramente interpretativo, es claro que la primera posición es insostenible, precisamente en virtud de la segunda condición general identificada más arriba. Si el artículo 915 contiene una excepción al artículo 895, dicha excepción debe estar contenida, sujeta a alguna condición especial de procedencia. No tiene sentido enunciar cuidadosamente una regla general y luego introducir una excepción que es aplicable a todos los casos. Pero eso es exactamente lo que hace la jurisprudencia que trata la acción del artículo 915 como una acción reivindicatoria que puede ser utilizada en contra del mero tenedor. Porque la regla general que exige posesión para la procedencia de la acción reivindicatoria (art. 895) tiene una consecuencia clara: excluye la acción reivindicatoria en el caso del mero tenedor. El artículo 895 podría haber sido formulado en negativo: "la acción de dominio no puede dirigirse contra el mero tenedor". Y si esta es la regla general, es absurdo añadirle después una excepción conforme a la cual hay acción reivindicatoria contra el mero tenedor. Ya hemos notado que esto no sería una excepción, sería una antinomia.

Y el texto del artículo 915 deja en claro que no pretende contener una regla contraria a la del 895, sino una excepción. Porque el artículo 915 intenta caracterizar con algún detalle aquel en contra de quien por excepción procede la acción que ese artículo concede: se trata de alguien que (a) posee a nombre ajeno primero, y después (b) retiene indebidamente la cosa. Y la acción procede incluso si esta indebida retención se hace "sin ánimo de dueño".

Es decir, se trata de quien adquirió el corpus como mero tenedor del dueño y detentó la cosa a nombre de este. Expirado el título de mera tenencia, retuvo la cosa. Esto no es lo mismo que una acción reivindicatoria contra el mero tenedor, por lo que satisface la segunda condición general indicada más arriba. Es una excepción que está debidamente delimitada y que tiene una explicación en términos del propio sistema de acciones.

Está debidamente delimitada: se aplica solo a los casos en los que el actor alega que el demandado tiene la cosa porque la recibió como su propio mero tenedor (del actor). Es decir, el actor no solo alega que la cosa es suya y no del demandado. Las condiciones de procedencia de la acción implican que corresponde al actor no solo probar la causa de la detentación del demandado, sino adicionalmente que esa causa es reconducible a él mismo

${ }^{87}$ Como describe esta posición Peñalitılo (2006), p. 533. 
(el actor), por lo que está excluida la posibilidad de que el demandado sea, por ejemplo, mero tenedor de un tercero que es poseedor y contra el cual debería ser dirigida la acción reivindicatoria, conforme a las reglas generales.

Como el artículo 915 es aplicable solo al caso en que el demandado tiene la cosa porque la ha retenido indebidamente después de que su obligación de restituir al actor se hizo exigible, el demandado podrá defenderse diciendo que ese no es su caso, lo que ocurrirá en dos situaciones: porque es mero tenedor de un tercero, y en ese caso se aplicará la regla del artículo 896 y el actor deberá dirigir su acción en contra de aquel a cuyo nombre el demandado posee. O porque es poseedor y entonces el demandante deberá usar la acción reivindicatoria.

Justificación de la excepción del artículo 915: es una acción relativa de dominio. La interpretación defendida en la sección anterior es más estrecha que la que se ha generalizado en la jurisprudencia chilena, que (infringiendo el segundo criterio interpretativo indicado más arriba) entiende que la acción del artículo 915 procede en contra de cualquier mero tenedor. Pero es más amplia que otra interpretación que ha sido defendida recientemente, la del profesor Javier Barrientos, que ha sostenido que la acción del artículo 915 procede solo en contra de quien "ha comenzado a poseer a nombre ajeno". "¿Quién es este 'poseedor a nombre ajeno'?". Barrientos responde haciendo referencia a los artículos 719 y 720 , que se refieren, el segundo, a la adquisición de la posesión mediante mandatario o representante legal ${ }^{88}$.

La interpretación aquí defendida es más amplia. En parte, por razones de texto: no hay razón alguna para entender que el "poseedor a nombre ajeno" al que se refiere el artículo 719 sea solo el mandatario o representante legal al que se refiere el artículo 720. En realidad, la referencia es a cualquiera que detenta reconociendo dominio ajeno, porque, como dispone el Mensaje, "el que a nombre ajeno posee, no es más que un representante del verdadero poseedor, ni inviste más que la simple tenencia". Esto podría invertirse: el mero tenedor no es más que un poseedor a nombre ajeno.

Ahora bien, la cuestión no puede ser solucionada mediante argumentos de texto, porque es necesario que la lectura del texto sea incorporada a una reconstrucción sistemática que muestre que la regla así entendida tiene sentido. Y efectivamente la delimitación de la procedencia de la acción del artículo 915 que hemos hecho en la sección anterior muestra su sentido. Porque si ella procediese en contra de todo mero tenedor, la pregunta es por qué la ley restringe la acción reivindicatoria al poseedor. Si la misma pregunta se formula a esta segunda interpretación, en que la acción reivindicatoria se extiende

${ }^{88}$ BarRientos (2005), p. 242. 
al que detentaba con un título de mera tenencia a nombre del propio actor pero se ha rehusado a restituir, la respuesta es evitar la desproporcionalidad: porque en esas condiciones el ejercicio de la acción reivindicatoria es más dificultoso y porque esa mayor dificultad sería innecesaria.

La acción reivindicatoria sería una acción especialmente difícil en este caso, precisamente porque se ha de dirigir en contra del poseedor. El demandado podrá decir que él no es poseedor, porque no reclama dominio sobre la cosa. Conminado a indicar a nombre de quién detenta la cosa, se produciría la situación absurda en que señalaría al propio demandante. ¡Y la acción sería rechazada! ${ }^{89}$.

Aquí conviene decir dos cosas: hay una razón por la que esto es menos absurdo de lo que parece. En efecto, si el demandado es mero tenedor del actor, el demandado tendrá que detentar o haber detentado la cosa con algún título. Ese título puede ser un contrato (como el caso del arrendatario) o un derecho real (como el caso del usufructuario). Si se trata de un derecho real que se extinguió, su contenido habrá revertido al dueño (art. 765 inc. final). Si el antiguo usufructuario persiste en su detentación de la cosa a título de usufructuario, estará poseyendo la cosa a título de usufructo, y el dueño podrá reivindicar el usufructo (art. 981 inc. $1^{\circ}$ ); si continúa detentándola pero ahora pretendiendo ser dueño, será poseedor.

Si por el contrario, su título de mera tenencia era contractual (como arrendamiento, comodato, etc.) el dueño tendrá la acción correspondiente al contrato respectivo. Aquí, sin embargo, surge un problema, porque las acciones personales pueden extinguirse por vía directa (el caso más obvio es la prescripción extintiva), pero las acciones reales no. ¿Cómo puede el dueño recobrar la tenencia de la cosa después de que la acción contractual en contra de su antiguo mero tenedor se ha extinguido?

En estricto rigor, podría usar la acción reivindicatoria, porque el antiguo mero tenedor se ha transformado en poseedor. Esta es la situación a la que se refiere el artículo 2510 regla tercera, la que la doctrina a veces y el propio Código entienden como una excepción a la regla del artículo 716. Conviene repasar someramente estas dos disposiciones.

Conforme al artículo 716, "el simple lapso de tiempo no muda la mera tenencia en posesión; salvo el caso del artículo 2510 regla $3^{\text {a" }}$. Ello porque el ánimo posesorio no es un estado mental del poseedor (no consiste en que el

89 Barrientos (2005), p. 242. Dice que en este caso "se habrá producido el 'allanamiento' a la demanda y el actor verá cumplida su pretensión". Esto es injustificado, porque el demandado podrá decir que el demandante no ha satisfecho las condiciones de ejercicio de la acción reivindicatoria, que suponen que el dueño no está en posesión de la cosa. 
poseedor se mire al espejo y se diga a sí mismo "soy dueño"). Es incorrecto sostener que la posesión es el resultado de la adición de dos elementos: un elemento objetivo o material, Ilamado "corpus", y un elemento subjetivo o inmaterial, intencional, Ilamado "animus" ${ }^{\prime}$. Si fuera así, habría que decir que el mero tenedor está a medio camino de ser poseedor, porque le falta solo uno de los dos elementos de la posesión. Y el que le falta es el elemento subjetivo, intencional: le basta creerse dueño. Por consiguiente, si durante la mera tenencia comienza a creerse dueño, la mera tenencia mutará en posesión.

Es precisamente esta consecuencia de la comprensión de la posesión como corpus y animus lo que el artículo 716 niega. El animus no es un estado mental, y por eso la mera tenencia nunca se muda en posesión. No es que el mero tenedor esté a medio camino de poseer, porque tiene el $50 \%$ de los requisitos: está tan lejos como el que no detenta, porque su detentación es a nombre ajeno. Lo que tiene que cambiar para que pase a ser poseedor no es su intención, es el modo en que detenta: debe dejar de detentar a nombre ajeno y pasar a detentar a nombre propio, que es lo mismo que vale para cualquier persona: cualquiera que comience a detentar a nombre propio una cosa será reconocido por la ley como poseedor.

Y ese es precisamente el caso al que se refiere el artículo 2510 regla tercera. No a que el solo lapso ("de tiempo") ha cambiado la mera tenencia en posesión (como lo implica la afirmación del art. 716 de que esta sería una excepción a esa regla), sino que ha cambiado el modo de detentación: el que detenta ya no reconoce dominio ajeno. La situación fáctica (que no la normativa) ha cambiado, y por eso, como la posesión es facticidad, lo mismo ha ocurrido con la situación posesoria. El antiguo mero tenedor es ahora poseedor.

¿En qué sentido ha cambiado la situación fáctica? El artículo 2510 no podría ser más claro: en el sentido preciso en el que lo indican las dos circunstancias

\footnotetext{
${ }^{90}$ No es posible hacer justicia a este tema en este contexto, observemos solamente que fue Ihering el que con más claridad percibió este punto. "El corpus, según la teoría dominante, es el poder físico, o la supremacía de hecho sobre la cosa. Tal es la noción fundamental según la teoría actual. Es absolutamente errónea", "porque la posesión no es el poder físico, sino la exterioridad de la propiedad". (IHERING (1974), p. 137). Es decir, lo que importa no es el poder físico, sino el modo en que la cosa se detenta por el dueño. Algunas veces esta detentación del dueño será mediante el control físico, otras no. El automóvil que se deja estacionado en la calle está en la posesión de su poseedor, incluso si lo deja abierto y con las llaves en su interior. Por consiguiente, habrá que decir que en el sentido relevante tiene lo que el artículo 700 llama corpus. Corpus, entonces, no puede ser entendido como la materialidad del control físico, debe ser entendido como la detentación de la cosa a la manera de los dueños: "Que se pregunte cómo el propietario suele obrar con sus cosas, y se sabrá cuándo es preciso admitir la posesión y cuándo se debe rechazar". (IHERING (1974), p. 137). Por eso el mero tenedor no tiene el $50 \%$ de lo que necesita para ser poseedor: aunque tiene la cosa bajo su control, no la tiene a la manera de los dueños.
} 
de su regla tercera. El antiguo mero tenedor ahora reclama dominio, pero no en el sentido de que ha decidido en su mente que ahora es dueño (eso es lo que está excluido por el art. 716), sino porque algo ha cambiado en el mundo de los hechos, porque (a) ha dejado de reconocer el dominio del antiguo dueño y (b) ha detentado como dueño públicamente.

Ahora bien, el artículo 2510 asume la perspectiva ex post: la de lo que puede decirse una vez transcurridos 10 años desde el momento en que esas dos circunstancias comenzaron a ser efectivas. Como asume la perspectiva ex post, el problema de determinar en qué momento eso fue así queda reducido a una cuestión de prueba. El artículo 915 asume la perspectiva ex ante: del dueño que observa que su mero tenedor se ha alzado y quiere evitarlo.

En rigor, entonces, la mejor manera que tendrá el dueño para mostrar que el mero tenedor ya no reconoce su dominio es mostrar que es un injusto retenedor, por lo que la acción debida es la reivindicatoria. Pero ejercer en este caso la acción reivindicatoria es problemático para el dueño, porque la situación está en transición y entonces es posible que no logre probar que el demandado es poseedor y que su acción reivindicatoria sea rechazada por no satisfacer la condición del art. 985. El rechazo de la acción reivindicatoria, por cierto, no afectaría sus derechos, porque podría intentarla nuevamente cuando la situación se haya estabilizado en el sentido de la regla tercera del artículo 2510. Pero además de que no tiene sentido alguno obligar al dueño a esperar que su antiguo mero tenedor sea indiscutiblemente poseedor para recuperar su cosa, nótese lo difícil que es la posición del dueño: se expone a que aunque el mero tenedor ya posee no pueda probar la posesión; se expone a que en el segundo intento se le oponga la excepción de cosa juzgada; se expone a que el antiguo mero tenedor invoque su demanda inicial como reconocimiento de su propia posesión, etc. Todos estos riesgos a los que queda expuesto el dueño son riesgos que, interpretando las reglas y los hechos correctamente, tienen adecuada solución. Pero la experiencia muestra que eso no es garantía suficiente. Es conveniente, en la medida en que es posible, dar al dueño algún modo de protegerse del mero tenedor alzado. Ese medio es precisamente la acción del artículo 915.

Porque exponer al dueño a todas esas vicisitudes es enteramente desproporcionado, en la medida en que como es una controversia entre el dueño y su antiguo mero tenedor, es posible solucionarla sin producir prueba absoluta del dominio. En las circunstancias, es fácil para el actor probar su mejor derecho a la cosa, producir prueba relativa: si el demandante puede probar que el demandado recibió la cosa de él como mero tenedor y que si todavía tiene el corpus es solo porque ha retenido indebidamente, no es necesario 
indagar más. Esto protege suficientemente al dueño de los riesgos de ejercer en esas condiciones la acción reivindicatoria.

\section{Prestaciones mutuas}

Prestaciones mutuas: ámbito de aplicación y cuestiones relevantes. En rigor, "prestaciones mutuas" son las que se deben recíprocamente el poseedor vencido y el dueño como consecuencia de la restitución de la cosa a la que ha sido obligado el poseedor. Sin embargo, la doctrina es unánime en que estas reglas se aplican en general a toda hipótesis de restitución ${ }^{91}$. El Código hace alusión a ellas de modo más o menos explícito, pero incluso cuando no hay alusión directa se ha entendido que son ellas las que regulan el tema. Hay alusión expresa en el artículo 1266, respecto de la restitución de frutos y mejoras en el caso de la acción de petición de herencia; hay una alusión directa, aunque no expresa, en la referencia que el artículo 1687 hace a las "reglas generales" que se aplican para determinar las prestaciones que se deban las partes como consecuencia de las restituciones que implique una declaración de nulidad. En otros casos la propia naturaleza del asunto puede implicar una solución distinta (en el caso de la resolución: véase el art. 1488). En lo que sea compatible, las reglas de las prestaciones mutuas se aplican (así, por ejemplo, el que debe restituir como consecuencia del cumplimiento de una condición se encuentra en cuanto a las mejoras en la posición del poseedor de mala fe, en tanto sabía de la existencia de la condición, etc.).

Es importante entonces caracterizar, por así decirlo, el tema de las prestaciones mutuas de modo genérico, para tener un criterio que permita determinar cuándo estas reglas se aplican. En general, estas reglas se aplican a los casos en los que una parte debe restituir a otra una cosa sin que la detentación de la cosa por quien debe restituir haya estado prevista y regulada por un contrato (en ese caso, como en el arriendo, se aplican las reglas contractuales respectivas) y están orientadas a determinar qué prestaciones se deben entre ellas. Como caracterización general, es útil la elaborada por Peñailillo:

A. Prestaciones del poseedor vencido al reivindicante

(i) Restitución de la cosa (arts. 904, 905).

(ii) Indemnización de los deterioros sufridos por la cosa (art. 906) y

(iii) Restitución de los frutos (arts. 907, 913).

B. Prestaciones del reivindicante al poseedor vencido

(i) Indemnización por las mejoras introducidas a la cosa.

91 Alessandri, Somarriva et al. (1957), p. 818; Peñallillo (2006), p. 542. 
Algunas observaciones generales. Aunque el Código la enumera dentro de ellas, y Peñailillo sigue al Código, no parece correcto incluir a la restitución de la cosa entre las prestaciones mutuas. Ello porque la restitución es en rigor la condición de la cual depende la aplicación de las reglas sobre esas prestaciones.

Peñailillo lista bajo "B" también los gastos de conservación de la cosa durante el juicio, si esta hubiera sido secuestrada (art. 904) y los gastos ordinarios necesarios para producir los frutos (art. 907 inc. final). Los primeros son inusuales, porque como la cosa está durante el juicio en posesión del demandado, la solución normal es que el demandado sea designado secuestre, por lo que no hay gastos (salvo la inscripción del embargo en el Registro del Conservador, en su caso). Los segundos no son un título especial de indemnización: es una regla para el cálculo de la indemnización que el poseedor vencido debe al dueño, en su caso, a propósito de los frutos, e implica que el costo necesario para producir los frutos será descontado de lo que deba pagar el poseedor.

Indemnización de las mejoras hechas a la cosa. Las reglas sobre prestaciones mutuas descansan en la necesidad de compatibilizar las exigencias de dos principios fundamentales para el Código Civil. Se trata de los principios que podríamos denominar de soberanía del propietario y de proscripción del enriquecimiento sin causa. En virtud del principio de soberanía del propietario, el dueño no puede ser responsabilizado por decisiones de inversión o mejora de la cosa que no ha tomado efectivamente; de acuerdo al principio de proscripción del enriquecimiento injustificado, el hecho de que como consecuencia del ejercicio exitoso de la acción reivindicatoria el dueño recibirá una cosa de mayor valor que el debido, a expensas del poseedor vencido, debe ser corregido mediante una transferencia patrimonial contraria que compense ese mayor valor.

Las reglas sobre prestaciones mutuas son notoriamente distintas de lo que serían si la ley atendiera solo a uno de estos principios. Eso muestra que esas reglas son un intento de compatibilizar exigencias que resultan contradictorias. Desde el punto de vista del principio de soberanía del dueño, no puede el dueño ser responsable del pago de ninguna mejora que no ha sido efectivamente querida por él. De acuerdo al principio de proscripción del enriquecimiento sin causa, toda mejora que ha aumentado el valor de la cosa debe ser indemnizada por el dueño.

El principio de soberanía del dueño descansa en la idea de que la protección de la propiedad es protección de la libertad del dueño. Jurídicamente hablando, esta libertad significa que la propiedad configura un espacio donde el dueño está legalmente justificado en actuar arbitrariamente. Esto no quiere 
decir, por cierto, que el derecho celebre la acción irracional, sino que el dueño no le debe cuentas a nadie respecto del uso que hace de su propiedad. La ley no exige al dueño que actúe con racionalidad ni con criterios de eficiencia económica respecto de su cosa.

Ahora bien, para determinar qué mejoras decididas por el poseedor vencido deben ser imputadas al dueño (es decir, qué mejoras han de ser tratadas como si hubieran sido queridas por el dueño, en el sentido de que será él el que tendrá que pagarlas) la ley distingue tres tipos de mejoras: necesarias, útiles y voluptuarias. La clasificación es estructurada por la magnitud de la interferencia con la soberanía del dueño que implica imputarle cada una de ellas.

Las mejoras necesarias son las inversiones que se justifican en la preservación de la integridad de la cosa en su dimensión funcionalmente principal. Para imputar estas inversiones al dueño, basta el supuesto de que el dueño está interesado en la preservación de la cosa en su dimensión funcionalmente principal. Asumir que el dueño tiene interés en seguir siendo dueño y está dispuesto a hacer las inversiones necesarias para eso es imputarle al dueño una voluntad que él no tiene deber alguno de tener, pero es una voluntad que normalmente el dueño tendrá (lo que puede decirse tanto en abstracto como en concreto, ya que el dueño ha hecho el esfuerzo de recuperar su cosa mediante el ejercicio de la acción reivindicatoria). La invasión de la soberanía del dueño existe, entonces, pero es sustantivamente limitada. Por eso, las mejoras necesarias se indemnizan al poseedor tanto de buena como de mala fe (art. 908).

Las mejoras útiles son mejoras que, sin ser necesarias, "aumentan el valor venal de la cosa" (art. 909 inc. $2^{\circ}$ ). Se trata de inversiones que son económicamente eficientes. Para imputárselas al dueño la ley tiene que asumir que el dueño está dispuesto a actuar racionalmente respecto de su cosa y a hacer inversiones que desde el punto de vista de la explotación económica de la cosa son razonables. De nuevo, el dueño no tiene deber alguno de querer esas inversiones. El supuesto de la ley para imputar las mejoras útiles es más invasivo que el que la ley necesita para imputarle las mejoras necesarias y por eso estas mejoras se indemnizan solo al poseedor de buena fe (art. 909).

Las mejoras que no son ni necesarias ni útiles son voluptuarias. Las mejoras voluptuarias son "las que solo consisten en objetos de lujo y recreo... que no aumentan el valor venal de la cosa, o sólo lo aumentan en una proporción insignificante" (art. 911). Es decir, son mejoras económicamente irracionales. El dueño desde luego puede decidir hacerlas (eso implica que pueda actuar a su arbitrio respecto de la cosa), pero la ley no tiene cómo imputarle en abstracto esas mejoras a un dueño que no las ha querido efectivamente. Por 
consiguiente, las mejoras voluptuarias no se indemnizan a ningún poseedor (art. 911).

Si una mejora no se indemniza, el dueño se enriquecerá y el poseedor se empobrecerá sin justificación. En la medida en que la ley persigue no solo evitar el enriquecimiento sin causa, sino hacerlo respetando la soberanía del dueño, ese es un resultado inevitable. Pero la ley pretende reducirlo todo lo que sea posible. Por eso, cada vez que una mejora no es indemnizada (es decir, tratándose de mejoras útiles hechas por el poseedor de mala fe y todas las mejoras voluptuarias) el poseedor tiene el ius tollendi, el derecho de retirar las mejoras si puede hacerlo sin detrimento de la cosa (arts. 910 inc. $\left.2^{\circ}, 911\right)$. El detrimento, por cierto, debe ser medido por referencia al momento anterior a la realización de la mejora (art. 912).

Siempre que la ley ordena que una mejora sea indemnizada, protege al crédito respectivo con un derecho legal de retención (art. 914).

Indemnización de los frutos y de los deterioros sufridos por la cosa. La regla para los deterioros sufridos por la cosa y para los frutos es fundamentalmente la misma: son indemnizados al dueño solo por el poseedor de mala fe. El poseedor de buena fe, por su parte, no responde. En lo que se refiere a los frutos, la regla no es fácil de justificar. Después de todo el dueño de la cosa se hace dueño de lo que la cosa produce (art. 643). En el juicio reivindicatorio ha quedado demostrado que el poseedor no tiene título para apropiarse de los frutos y, sin embargo, la ley no le impone la obligación de indemnizar. La sola apelación a la buena fe no es suficiente para justificar la apropiación por el poseedor de frutos ajenos. Parte de la explicación ha de estar en que una regla contraria resulta injusta con el poseedor, que actuó respecto de la cosa como si fuere suya y ajustó

su tren de vida a las rentas que creía tener. Sería arruinarlo obligarlo a reembolsar una suma equivalente tal vez a los gastos diarios que ha hecho quizás por numerosos años y que no podría pagar sino sustrayéndola a su capital, precisamente porque los frutos se han gastado ${ }^{92}$.

En lo que se refiere a los deterioros, la regla se justifica porque el poseedor actuó, durante su posesión, como dueño de la cosa, sin tener razón para mostrar respecto de ella ningún estándar de diligencia (el dueño puede lícitamente actuar "arbitrariamente" respecto de su cosa). Solo desde el momento en que sabe que tiene una cosa sobre la que hay otro que reclama dominio

92 Alessandri, Somarriva et al. (1957), p. 822. Citando a R. DekKers (1954), pp. 655-656. 
se dan las condiciones para imputarle un nivel normal de diligencia en su trato con la cosa.

El inciso $2^{\circ}$ del artículo 906 contiene una excepción para el caso del poseedor de buena fe: responde de los deterioros "en cuanto se hubiere aprovechado de ellos". El Código incluso da un ejemplo: "destruyendo un bosque o arbolado, y vendiendo la madera o leña". Esta regla parece en conflicto con la que exime al poseedor de buena fe de la obligación de indemnizar los frutos.

Es curioso el juicio de cada una de ellas. Respecto de la obligación de indemnizar los deterioros en el caso excepcional que estamos considerando, Alessandri y Somarriva dicen que esa obligación "resulta lógica", pues "en este caso se ha enriquecido y no es equitativo que se enriquezca a costa ajena" ${ }^{\prime \prime}$. Eso es, sin embargo, exactamente lo que ocurre con los frutos, respecto de los que, como hemos visto, la obligación de indemnizar "conduciría a una injusticia" ${ }^{\prime 94}$.

¿Cómo deslindar los casos de aplicación de una regla y otra? Al final de su explicación de por qué el poseedor de buena fe no debe indemnizar los frutos, Alessandri y Somarriva dan una razón que puede ser usada como criterio: "en resumen, el propietario conserva su capital y, con él, la esperanza de frutos futuros". Esto permitiría distinguir casos, usando la distinción entre productos y frutos ${ }^{95}$ : cuando el poseedor se ha enriquecido sin afectar el capital, porque se ha apropiado de frutos, rige el artículo 907 inciso $3^{\circ}$ y no debe indemnizar; cuando su enriquecimiento sí ha afectado al capital, porque se ha apropiado de productos, vale el artículo 906 inciso $2^{\circ}$ y debe indemnizar. Esto implicaría tratar al poseedor de buena fe como usufructuario (art. 783). En todo caso, la posibilidad de arruinar al poseedor vencido existe aquí también, lo que hace relevante el hecho de que el fundamento del derecho del dueño a ser indemnizado no es su dominio, sino el enriquecimiento del poseedor. El poseedor responde de los deterioros solo "si se hubiere aprovechado de ellos". Para evitar la ruina injustificada del poseedor, el cálculo de ese aprovechamiento debe seguir la regla que contiene el artículo 1688 inciso $2^{\circ}$ para el incapaz.

Como ya hemos visto, el poseedor de buena fe debe los frutos desde la notificación de la demanda. Esto suele justificarse diciendo que desde ese momento el demandado está de mala fe. Es dudoso, sin embargo, que se

\footnotetext{
93 Ibid.

${ }^{94}$ Ibid.

${ }^{95}$ Ibid.
} 
justifique esta afirmación. La sola notificación de la demanda no tiene por qué llevar al poseedor al convencimiento de que el demandante es dueño de la cosa.

Quizás las observaciones anteriores puedan unirse en una. Hemos visto que la razón por la que la ley permite al poseedor de buena fe no indemnizar los frutos que en principio debería indemnizar es que el poseedor quedaría expuesto a una obligación que puede ser notoriamente pesada sin haber tenido aviso alguno. Desde el momento en que ha recibido ese aviso, puede adoptar las providencias necesarias para enfrentar la obligación de pagar. Contrariamente a lo que ocurre con el poseedor de buena fe, el de mala fe está siempre sobre aviso de que en algún momento puede aparecer el verdadero dueño y reclamar la cosa.

La racionalidad de la obligación del poseedor de buena fe de indemnizar los deterioros es distinta de la de indemnizar los frutos. La regla del primer caso se basa en el enriquecimiento del poseedor más que en el dominio del dueño. La del segundo es precisamente inversa y se funda no en el enriquecimiento del poseedor, sino en el derecho del dueño en tanto dueño a los frutos. Esto fluye claramente del artículo 907:

"El poseedor de mala fe es obligado a restituir los frutos naturales y civiles de la cosa, y no solamente los percibidos sino los que el dueño hubiera podido percibir con mediana inteligencia y actividad, teniendo la cosa en su poder".

El sentido de esta regla es que lo que el poseedor de mala fe debe restituir en cuanto a los frutos se determina en abstracto, no en concreto. Aquí se trata de alguien que, a sabiendas, detenta una cosa ajena, por lo que esa detentación es contraria a derecho. Al detentar causó daño al interés del dueño, daño consistente en el solo hecho de que, ilícitamente, impidió que el dueño destinara su cosa al uso adecuado. Este daño es un daño normativo, no fáctico. Lo afectado fue la posición normativa del dueño respecto de la cosa, no su patrimonio. En otras palabras, el daño se verifica por el hecho de que el dueño haya estado privado de la detentación, no porque al estar privado de la detentación ha sufrido efectivamente una merma patrimonial o no ha recibido un incremento. Es por eso que el daño se aprecia en abstracto (su valor está dado por lo que una persona normal, con mediana inteligencia y actividad, habría podido obtener del predio) y no en concreto, es decir, para la determinación del daño no es necesario hacer referencia a la persona del dueño o a lo que este efectivamente habría hecho con la cosa si la hubiere tenido en su poder. Quizás el demandante no habría explotado la cosa si la hubiera tenido en su poder; quizás la habría explotado de un modo 
particularmente inepto, obteniendo por ello una pérdida del que el hecho de no tener la cosa en su poder lo ha, afortunadamente, librado; quizás, en fin, la habría explotado de modo insospechadamente exitoso, obteniendo una utilidad mucho mayor a la previsible. El artículo 907 declara todas estas circunstancias irrelevantes, porque lo que importa es el valor de mercado de la afección que ha sufrido el dueño al no poder detentar su cosa, no lo que el dueño habría efectivamente ganado si la hubiera tenido. Y el valor de mercado de detentar la cosa es lo que la cosa normalmente habría producido. El poseedor vencido no se beneficia del hecho de que el dueño sea especialmente inepto para explotar cosas como esa, ni es perjudicado por el hecho de que el dueño sea un sagaz explotador de ese tipo de cosas.

\section{JURISPRUDENCIA CITADA}

Paredes con Barrera, sentencia de la Corte Suprema de 24 de mayo de 2005, rol No 4718-03.

Arriagada con Fisco, sentencia de la Corte Suprema de 18 de abril de 2005, rol No 2846-2003.

Cárdenas con Báez, sentencia de la Corte Suprema de 4 de junio de 2014, rol No $178-2014$.

\section{BiBLIOGRAFÍA CITADA}

Alessandri, A. (1937): De los bienes. Versiones taquigráficas tomadas en la clase de derecho civil por Onías León Gaete (Santiago, Zamorano y Caperán).

Alessandri, A.; Somarriva, M. y Vodanovic, A. (1957): Curso de Derecho Civil, $2^{a}$ edición (Santiago, Nascimento).

Alessandri, A.; Somarriva, M. y Vodanovic, A. (1998): Tratado de los derechos reales (Santiago, Editorial Jurídica de Chile).

Álvarez, H. (1928): La inscripción no es requisito, garantía ni prueba de la posesión de los bienes raíces (Santiago, Imprenta y librería "Artes y Letras").

AtrIA, F. (2013): "Derechos reales", en: Revista de Derecho de la Universidad Adolfo Ibáñez (Vol. 3, № 3), pp. 13-73.

AtriA, F. (2018): “El sistema de acciones reales, parte especial. La dimensión dinámica del dominio", de próxima aparición en: Revista Chilena de Derecho Privado. 
AtRIA, F. (2017): "El sistema de acciones reales, parte especial: la acción de precario", en: Revista de Derecho de la Universidad Austral (Vol. 32 $\mathrm{N}^{\circ}$ 2, pp. 57-86).

Atria, F. y SAlgado, C. (2016): La propiedad, el dominio público y el régimen de aprovechamiento de aguas en Chile (Santiago, Thomson Reuters).

BARCIA, R. (2014): "De los bienes y de su dominio, posesión, uso y goce", en: Revista Chilena de Derecho Privado (Vol. 23, № 12), pp. 367-390.

BARCIA, R. (de próxima aparición): "La concurrencia de acciones reales a la luz de la jurisprudencia de la Corte Suprema en torno a la posesión material", en: Revista de Derecho de la Universidad Católica del Norte.

Barrientos, J. (2005): "De los bienes y de su dominio, posesión, uso y goce", en: Revista Chilena de Derecho Privado (Vol. 4, № 3), pp. 221-249.

Barros, E. (1996): "El recurso de protección como medio de amparo de los contratos", en: FundaCIÓN FERNANDO FueYo, Instituciones modernas de derecho civil: homenaje al profesor Fernando Fueyo Laneri (Santiago, Editorial Jurídica ConoSur).

BIRKS, P. (1998): "Before we begin. five keys to land law", en S. BRIGHT y J. DewAR (eds.), Land Law. Themes and perspectives (Oxford, Oxford University Press).

Caballero, G. (2016): La custodia en el mercado de valores (Santiago, Thomson Reuters).

CHACÓN, J. (1881): Exposición razonada y estudio comparativo del Código Civil chileno (Valparaíso, Imprenta El Mercurio).

Claro Solar, L. (2013): Explicaciones de Derecho Civil chileno y comparado (Santiago, Editorial Jurídica de Chile).

COOKE, E. (2012): Land Law (Oxford, Oxford University Press).

Domínguez Águila, R. (2005): "Instituciones jurisprudenciales en el Código Civil chileno", en: M.D. Martinic y M. Tapia (eds.), Sesquicentenario del Código Civil de Andrés Bello (Santiago, LexisNexis).

Figueroa, G. (1991): El patrimonio (Santiago, Editorial Jurídica de Chile).

Guzmán BRITO, A. (1995): Las cosas incorporales en la doctrina y en el derecho positivo (Santiago, Editorial Jurídica de Chile).

Halabí Riffo, F. M. y SAfFirio SuÁrez, C. A. (1996): La acción de precario ante la doctrina y la jurisprudencia (Santiago, ConoSur).

Hernández GiL, A. (1967): La función social de la posesión (Madrid, Real Academia de Jurisprudencia y Legislación).

IHERING, R. (1892): La teoría de la posesión (Madrid, Imprenta de la Revista de Legislación). 
IHERING, R. (1974): "La posesión. Teoría simplificada", en: Ihering: Estudios Jurídicos (Buenos Aires, Heliasta).

JANA, A. y MARín, J. C. (1996): Recurso de protección y contratos (Santiago, Editorial Jurídica de Chile).

Kiverstein H., A. (2006): Síntesis del Derecho Civil: De los objetos del Derecho: Bienes, $5^{a}$ ed. (Santiago, La Ley).

Larroucau, J. (2014): "La prueba completa del dominio en la acción reivindicatoria", en: Estudios de Derecho Civil IX (Santiago, LegalPublishing).

Larroucau, J. (2015): "Acciones reales y estándares de prueba", en: lus et Praxis (Vol. 21, Número 2), pp. 109-160.

LATHROP, F. (2011): “Diferencias entre la acción de demarcación y la acción de reivindicación. Comentario sentencia Corte Suprema de 17 de agosto de 2010, rol № 5565-2010", en: Revista de Derecho. Escuela de Postgrado, Universidad de Chile (Vol. 1, № 1), pp. 257-261.

Peñallillo, D. (2006): Los bienes (Santiago, Editorial Jurídica de Chile).

PÉREZ, M. F. (2014): "La protección del dueño ante quien retiene indebidamente un bien, análisis jurisprudencial del artículo 915 del Código de Bello", en: Revista de Derecho (Coquimbo) (Vol. 21, № 1), pp. 387-421.

Pescio, V. (1978): Manual de Derecho Civil (Santiago, Editorial Jurídica de Chile), Vol. 4.

Rostión, I. (2013): El precario en la jurisprudencia chilena (Santiago, Legal Publishing).

Rozas, F. (1998): Los bienes (Santiago, ConoSur).

Selman, A. (2011): "Artículo 915 del Código Civil: una solución jurisprudencial a la limitación de las acciones tradicionales", en: lus et Praxis (Vol. 17, № 1), pp. 57-80.

Trucco, H. (1910): "Teoría de la posesión inscrita dentro del Código Civil chileno", en: Revista de Derecho y Jurisprudencia (vol. 6), pp. 131-155.

Veloso Chávez, A. (1947): La reivindicación (Santiago).

Vera, R. (1894): Comentario del Código Civil (Santiago).

Vergara, A. (2001): "La summa divisio de los bienes y recursos naturales en la Constitución de 1980", en: E. NAVARro (ed.), Veinte años de la Constitución de 1980 (Santiago, Universidad Finis Terrae).

Westermann, H.; Westermann, H. P.; Gursky, K.-H. y Eickmann, D. (2007): Derechos reales, $7^{\text {a }}$ edición (traducc. A. Cañizares et al., Madrid, Fundación Cultural del Notariado). 